\title{
الاستفادة من التراكيب النسجية المنفذة على النول اليدوي في إثراء القيمة الجمالية لملابس الأطفال
}

\section{Benefits of Weaves Construction carried out at The Hand loom to Enrich the Aesthetical Values of Children's Clothing} د/ بسمة عبد المنصف فايا درويش مدرس الملابس والنسيج، كلية التربية النوعية، جامعة المنوفية.

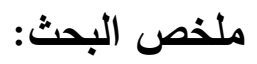

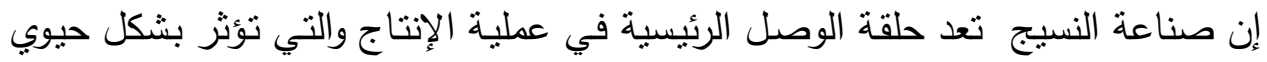

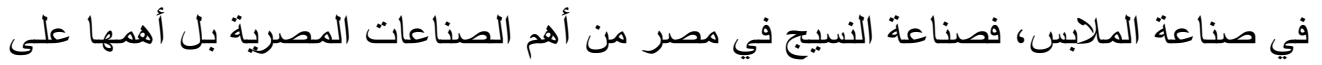

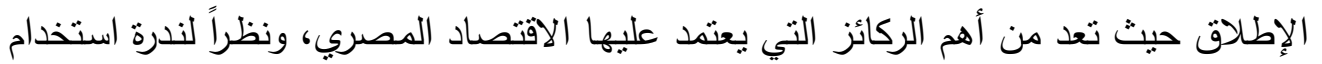

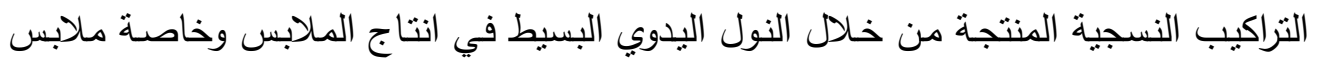

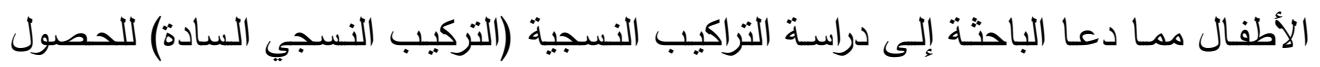

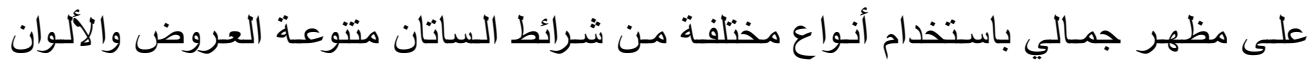

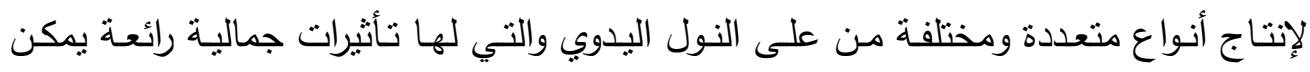

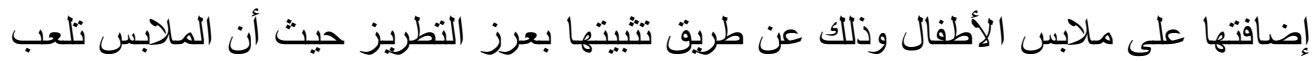

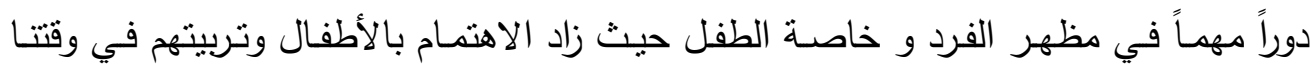

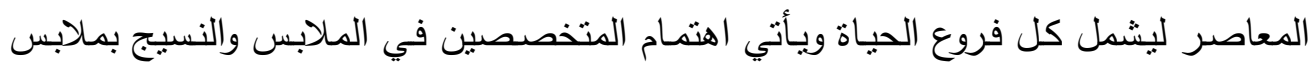

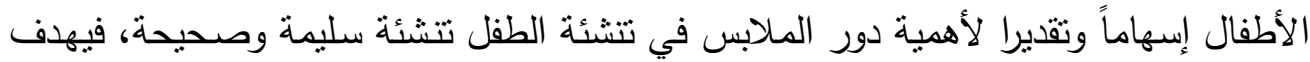

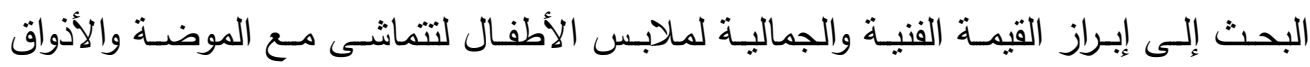

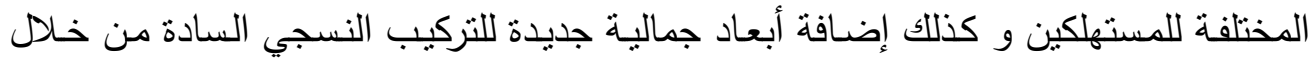

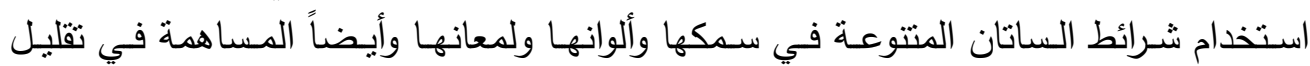
النفقات المستخدمة في صناعة ملابس الأطفال.

\section{Research Summary:}

The textile industry is the main link in the production process, which dynamically affect the apparel industry, Textile making in Egypt, the most important of Egyptian Industries, but most important of all, where is one of the most important pillars upon which the Egyptian economy, due to the scarcity of the use of compositions textile produced through the loom simple hand in the production of clothing, especially children's clothing, prompting a researcher to study the compositions histological (installation histocompatibility gentlemen) for aesthetic tissue structures Using different types of satin ribbons variety of offerings and colors to produce many different types of textile structures on handloom and which have wonderful 
aesthetic effects can be added to the children's clothes through the installed Bars embroidery as clothing plays an important role in the appearance of the individual, especially a child, where increased attention children and upbringing of our time to include all branches of life comes the attention of specialists in the clothing and textile clothes children contribution in recognition of the importance of the role of clothing in the upbringing of the child-rearing sound and correct, aims research to highlight the artistic and aesthetic value of children's clothing to go along with fashion and different tastes of consumers, as well as adding new aesthetic dimensions for installation histocompatibility gentlemen through the use of diverse satin ribbons in thickness, colors and brightness and also contribute to reduce costs used in the children's clothing industry. 


\section{المقدمة ومشكلة البحث:}

تمثل صناعة النسيج حلقة الوصل الرئيسة في عملية الإنتاج والتي تؤثر بشكل حيوي في صناعة الملابس، فتعتبر صناعة النسيج في مصر من أهم الصناعات المصرية بل أهمها

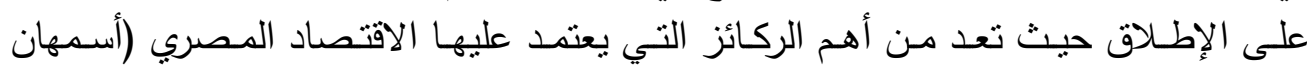

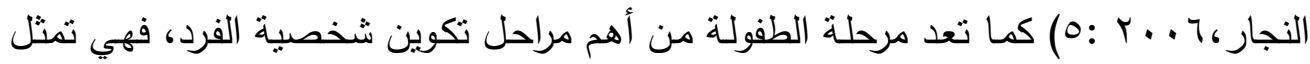

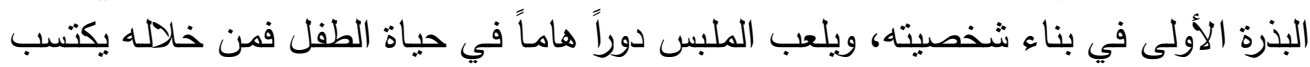

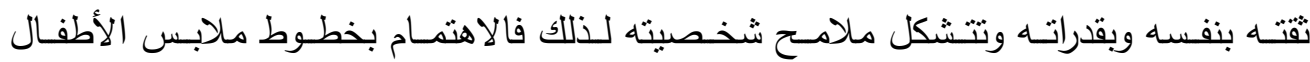

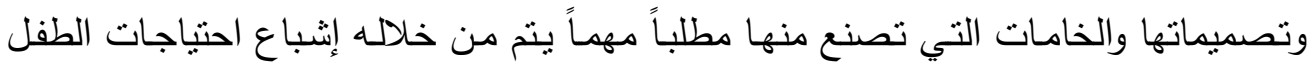
وفقاً لمراحل نموه (عفاف كمال علي محمود: .... ب، ( ). ولقد زاد الاهتمام بالأطفال وتربيتهم في وقتتا المعاصر ليشمل كل فروع الحياة ويأتي اهتمام المتخصصين في الملابس والنسيج بملابس الأطفال إسهاماً وتقديرا لأهمية دور الملابس في في تتشئة الطفل تتشئة سليمة وصحيحة، لما بستطيع أن يكتسبه الطفل من عادات ومهارات، وسلوكيات قد تساهم في تشكيل شخصية المستقبل لتكون شخصية اجتماعية وذات بنية جسمية صحيحة بدون معوقات أو نشوهات جسمية (منا موسى، نجده ماضي:0 . . Y، V).

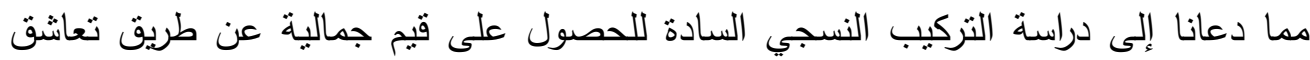
مجموعتين من الخيوط الأولى تعرف باسم خيوط السداء Warp وهي التي تكون أساساً موضوعة على النول في وضع طولي، والثانية تعرف باسم خيوط اللحمة Weft وهي التي تمر لترفي أعلى وأسفل خيوط السداء في وضع أفقي وذللك باستخدام النول The Loom. لذلك يمكن استخدام أنواع مختلفة من شرائط الساتان منتوعة العروض والألوان ومختلفة السمك لإنتاج أنواع متعددة ومختلفة من التركيب النسجي السادة على النول اليدوي والتي لها تأثيرات جمالية رائعة يمكن إضافتها على ملابس الأطفال وذلك عن طريق تثبيتها بغرز

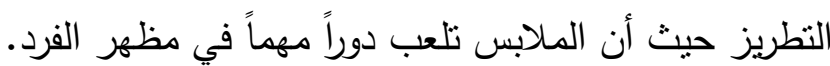
ويمكن صياغة مشكلة البحث في صورة التساؤل الرئيسي التالي: ما مدى إمكانية الاستفادة من التركيب النسجي السادة المنفذ على النول البدوي في إثراء

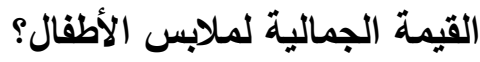

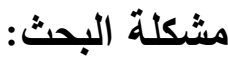

ا. ما مدى مناسبة التركيب النسجي السادة المنتجة يدوياً في إثراء القيم الجمالية لملابس الأطفال؟ ץ. ما مدى إمكانية الاستفادة من التركيب النسجي السادة لتفيذ أشكال متتوعة تتتاسب مع إن

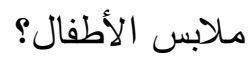


1. إبراز القيمة الفنية والجمالية لملابس الأطفال لتتمانشى مع الموضة والأذواق المختلفة.

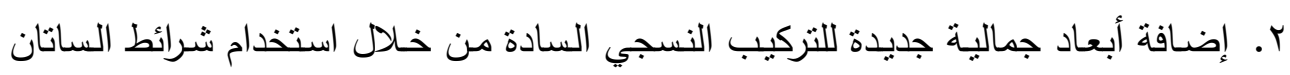
المتتوعة في سمكها وألوانها ولمعانها. r. المساهمة في تقليل النفقات المستخدمة في صناعة ملابس الأطفال.

$$
\text { هدف البحث: يهذف البحث إلى: }
$$

ا ـ الاستفادة من التراكيب النسجية لإثراء القيم الجمالية لملابس الأطفال

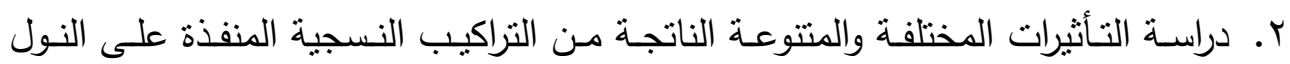
اليدوي باستخدام شرائط الساتان. فروض البحث: ويتبنى هذا البحث الفروض التالية: ا . توجد علاقة ذات دلالة إحصائية بين درجة قبول ونجاح الملابس المنفذة ومدى تحقيق مستوى الأداء الجمالي للتركيب النسجي وفقا لآراء المحكمين.

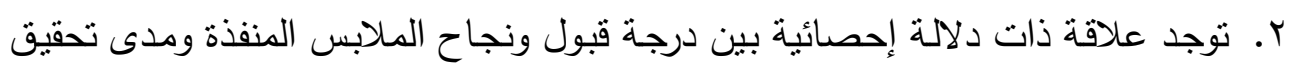
مستوى الأداء الجمالي للتركيب النسجي وفقا لآراء المستهلكين. حدود البحث: الحد الزمني : تم اجراء التجربة في يناير 17 • بادم الحد المكاني : كلية التربية النوعية جامعة المنوفية

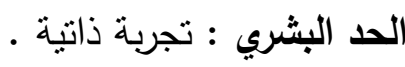

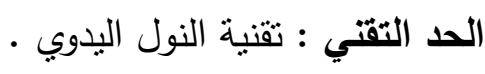
التركيب النسجي السادة باستخدام (شرائط الساتان متتوعة العروض والألوان).

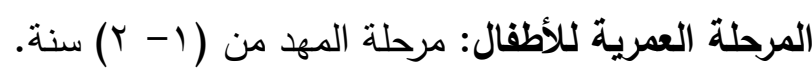
ملابس الأطفال (البلوزة - جاكيت) . منهج البحث: يتبع البحث المنهج الوصفي والمنهج التجريبي. أدوات البحث: استمارات تقييم منتج ملبس وقطع منسوجة بنسيج السادة بشرائط الساتان. الادراسات السابقة: هناك العديد من الدراسات السابقة في كل من مجال التراكيب النسجية فئسية والقيم الجمالية وملابس الأطفال وهم كالتالي: 


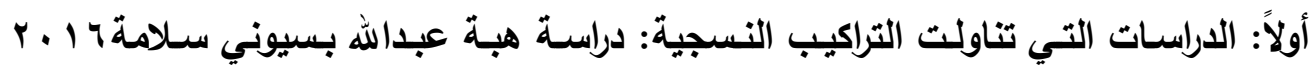

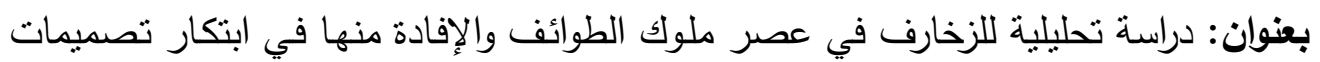

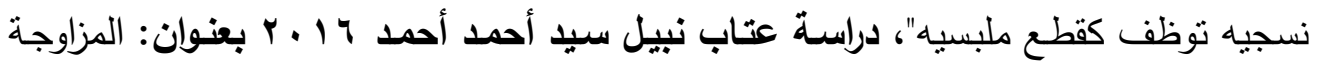

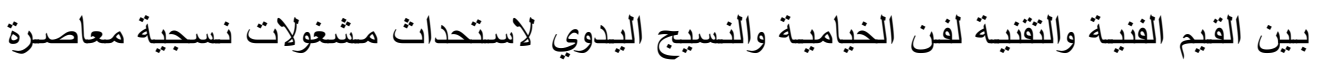

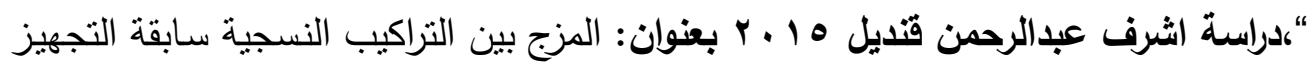

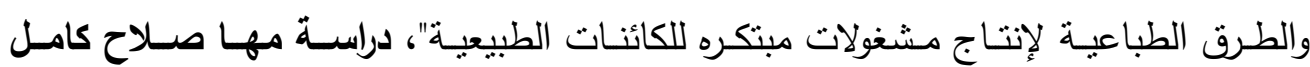

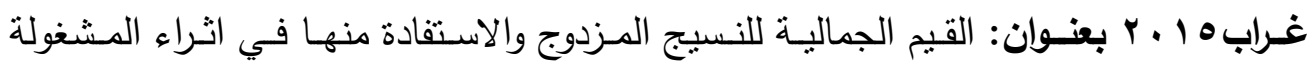

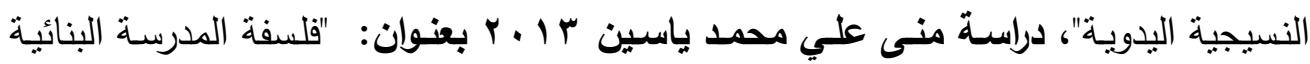

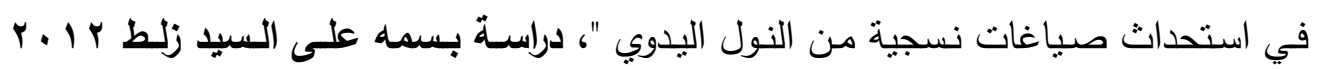

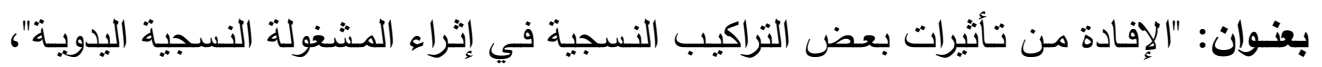

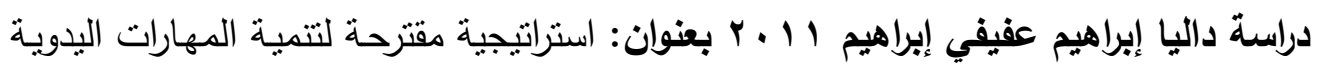

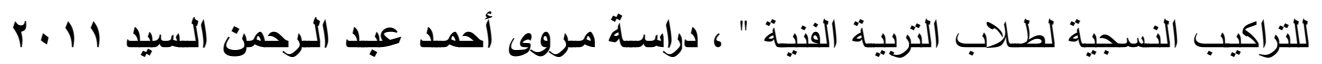

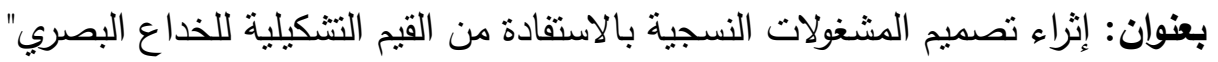

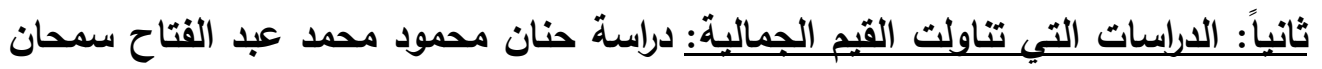

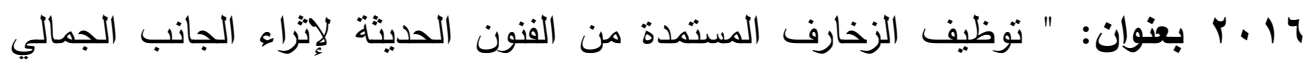

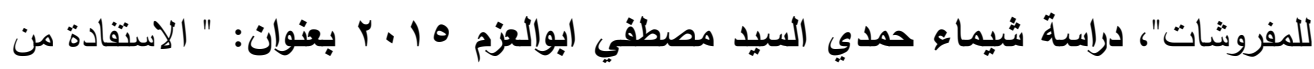

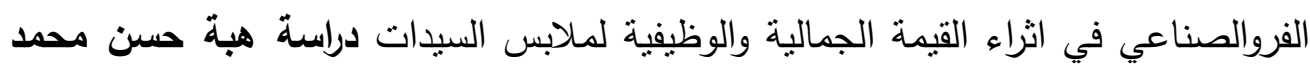

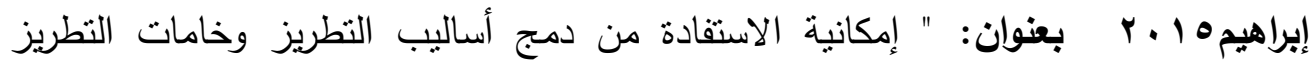

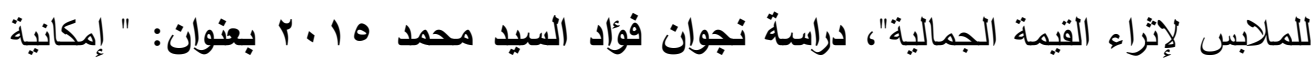

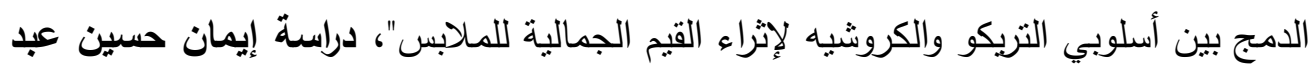

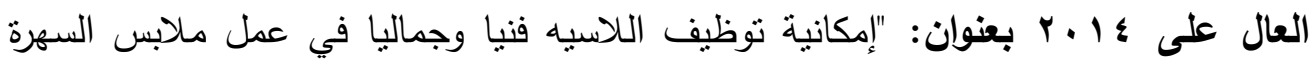

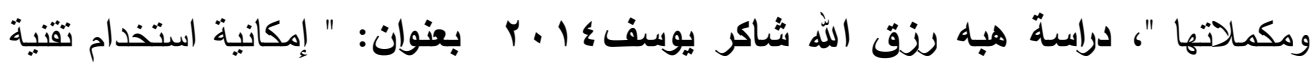

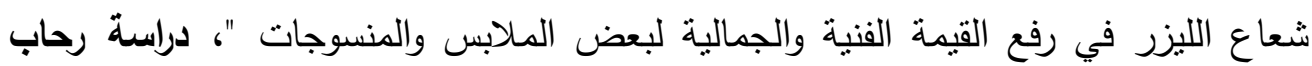

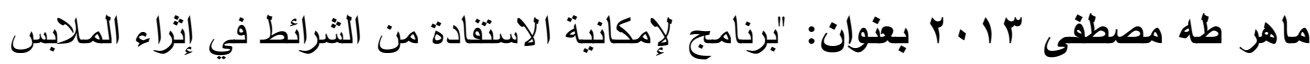

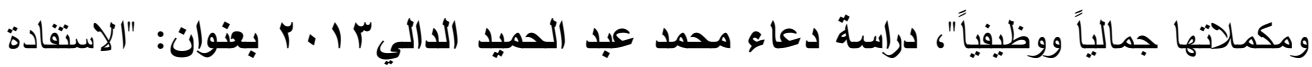

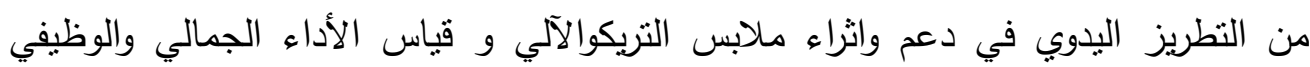

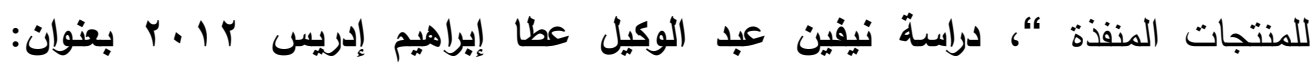

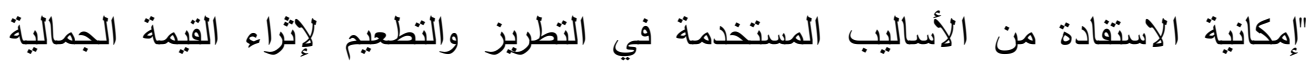
لملابس السيدات ومكملاتها". 


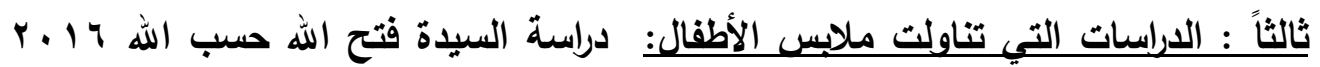

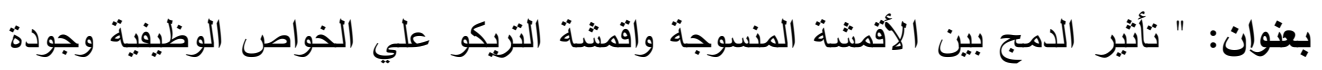

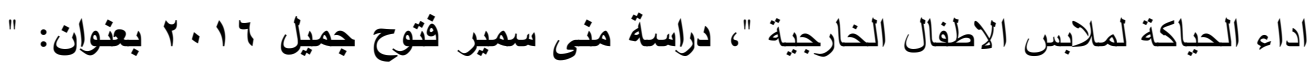

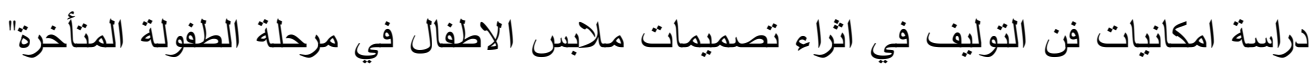

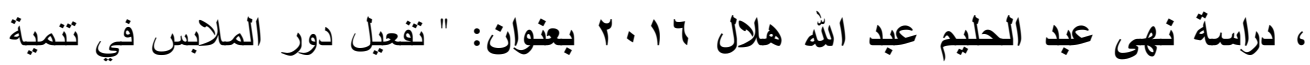

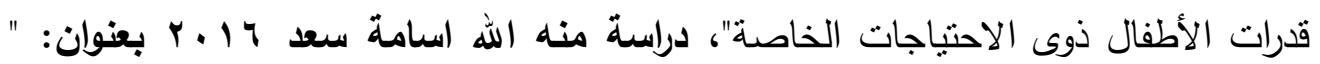

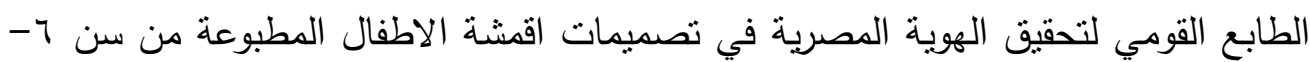

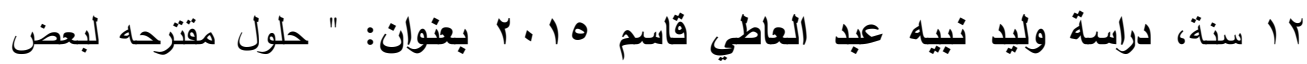

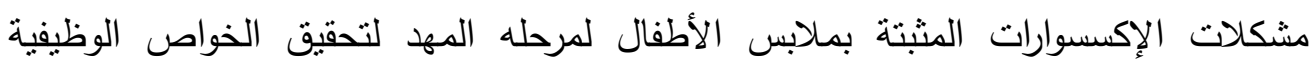

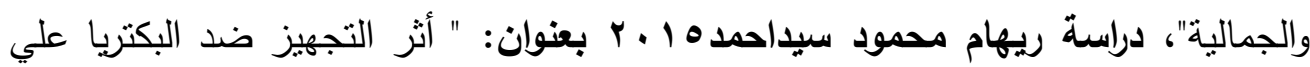

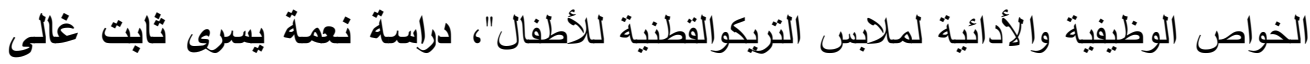

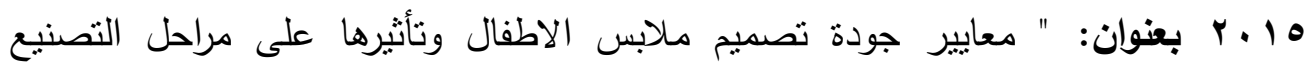

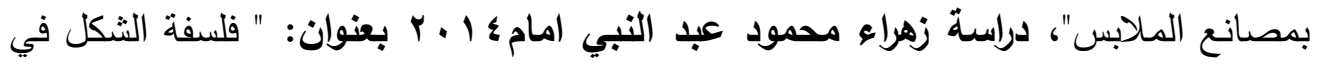
رسوم اطفال العالم للبيئة المصرية لطباعة تصميمات اقمشة ملابس الأطفال" .

\section{مصطلحات البحث:}

1 - (التراكيب النسيجية Weaves Construction): هي عبارة عن تقاطع خيوط السداء

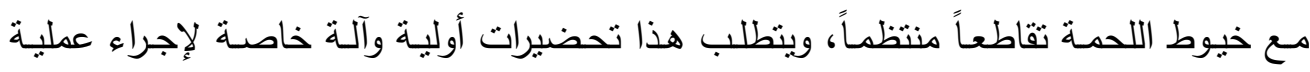

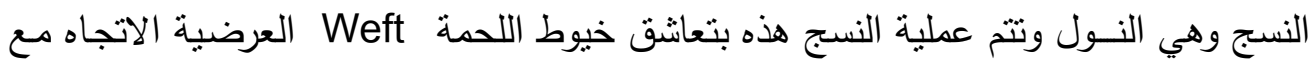

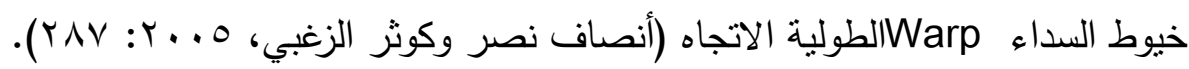

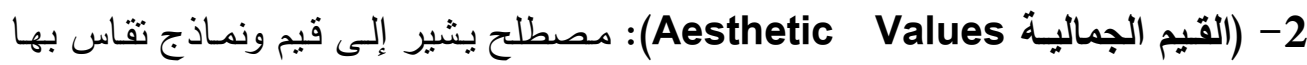

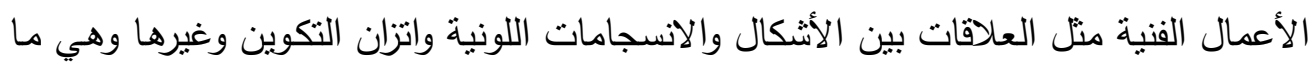

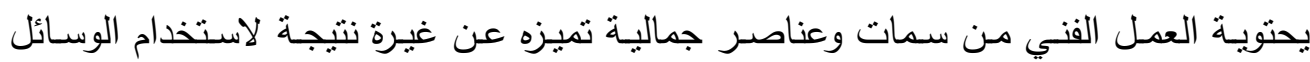

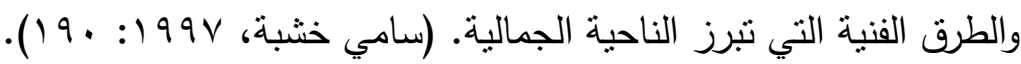
r- (الملابسس(Clothes): هـي كل مـا يلبس ليحمسي الجسد البشري مـن الطقس والبيئة الخارجية (www. ar.wikipedia.org) الإطار النظري للبحث:

Plain Weave التركيب النسجي السادة يعتبر النسيج السادة من أهم وأبسط التراكيب النسجية استخداما نظراً لسرعة إنتاجهـ

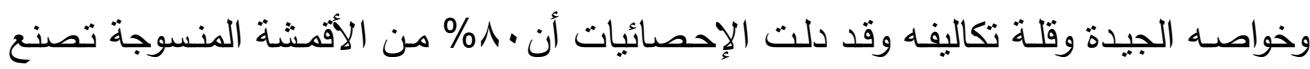


بطريقة النسيج السادة وذلك لسهولة صباغته وسهولة تتظيفه وزيادة العمر الاستهلاكي لمتانتها

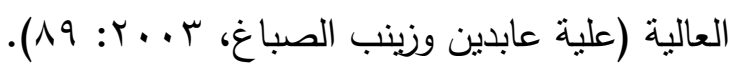

كما يتميز بإكساب الأقمشة الناتجة بعض الخواصناص الطبيعية مثل المتانة نتيجة لاندماج

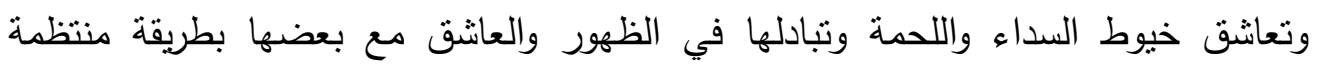

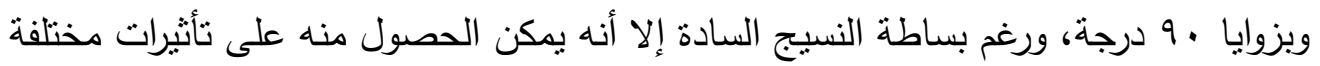
تؤُثر تأثيرا" مباشرا" في مظهر وملمس القماش الناتج مع الغرض من الاستخدام، وهو يتكون

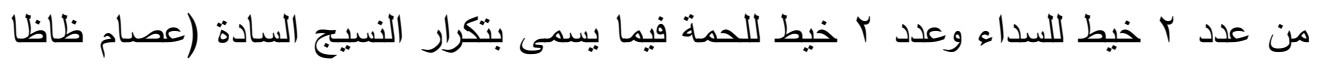

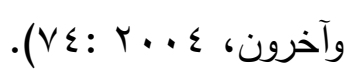

ويستخدم النسيج السادة في إنتاج أخف الأقمشة وزناً وأكثرها تماسكاً، وتؤدي قلة الفراغات داخل التركيب النسجي السادة إلى نفاذيته للرطوبة حيث تتوقف أيضاً على نوعية الخامة

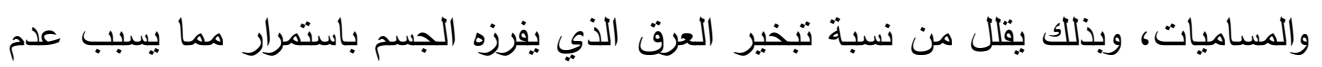

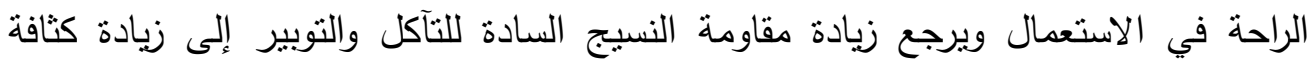

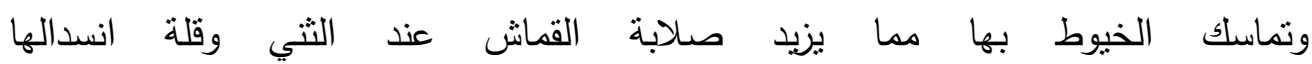
.(Scrivano,Sandy, 1998:23)

\section{Variations in plain weave: التنوع في النسيج السادة}

إن استخدام قاعدة النسيج السادة في إنتاج أقمشة دون نتوع لا تعطي له مظهراً جذاباً

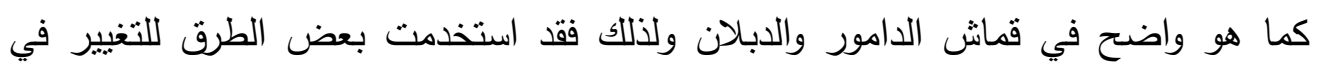
مظهر النسيج وإخراجه في صور منتوعة لا حد لها نتيجة لابتكارات مصممي الأنسجة وحسن

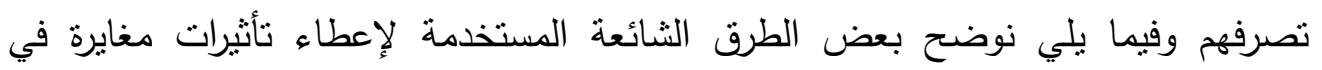

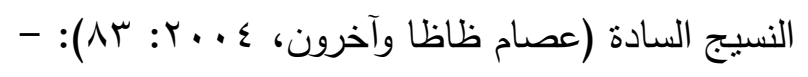

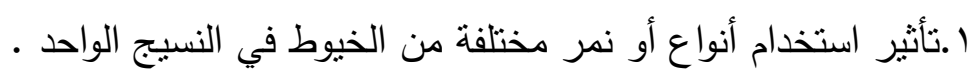

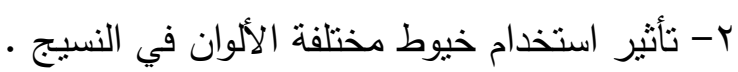
ب-تأثير ناتج من التجهيزات الختامية .

\section{القيم الجمالية Aesthetical -Values:}

تقرر النظريات الجمالية أن الخاصية الجمالية ليست شيئاً ثابتاً للأشياء لكنها في الحقيقة ترجع إلى العلاقات بين العقل الإنساني وارتباطه بالقيم الإنسانية بصفة عامة. 
فالقيم الجمالية: مصطلح يثير إلى قيم ونماذج تقاس بها الأعمال الفنبة مثل العلاقات بين

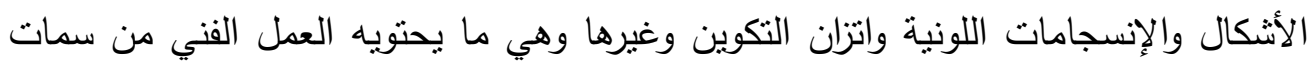

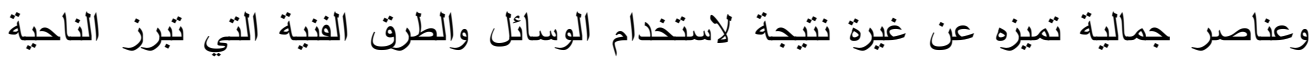

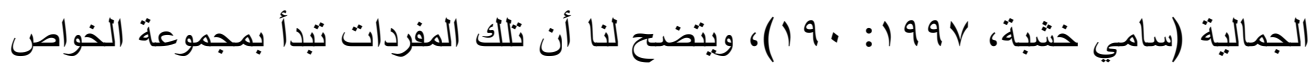
البصرية (اللون - اللمعان - الثفافية ) تليها مجموعة أخرى من الخواص المرتبطة بالتأثير السطحي الذي تراه وتشتعر به العين قبل اليد منها (المظهر السطحي - هيئة قوام القماش بهن

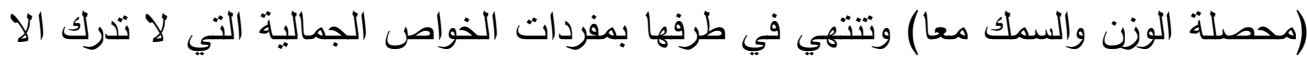

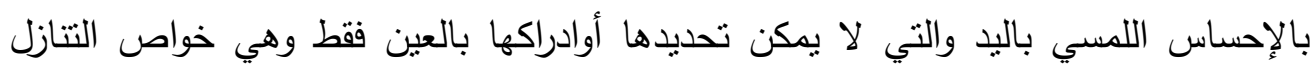
باليد الذي يمكن من خلاله (اللمس) أن نحدد مدى رجوعية الانضغاط للقماش وأيضا الاحساس بقوام القماش ( 58 : John gillow\& Bryan Sentence, 1999).

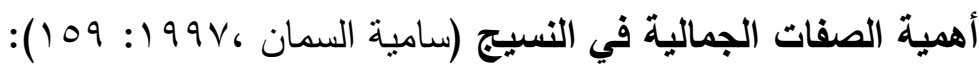
- - الملمس طريقة لبيان أن النسيج مرنا ومتماسك. - اللون يمكن رؤيته من بعد كمشاركة في صفات النسيج. -

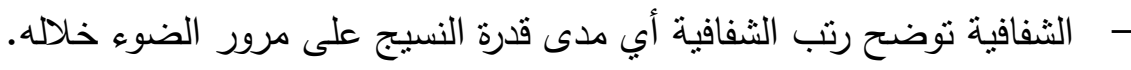
- اللمعان توضح درجات انعكاسات الضوء على الأنسجة. - - الصلابة تبين مدى استعمالات الأقمشة. - - ملقوام يوضح الوزن والثبات للأنسجة.

ملابس الأطفال (Children's Clothing) في مرحلة المهر:

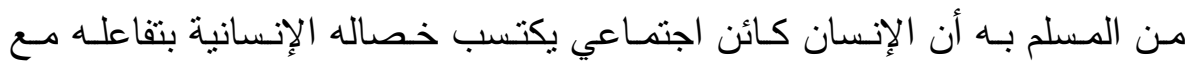
الآخرين الذين يعيشون معه، وأن الخصائص الإنسانية قابلة للتغيير والتشكيل، وبعضها قابل الإبل

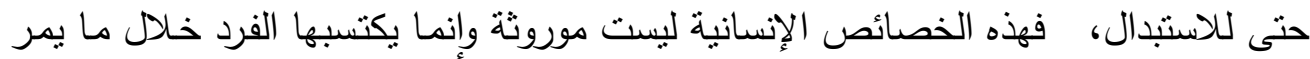

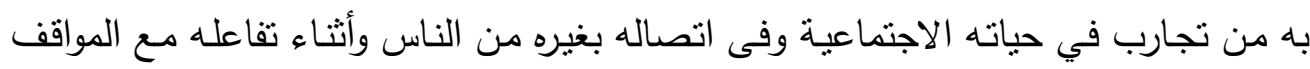
التي يمر بها بما تحويه هذه المواقف من عوامل كثثرة منداخلة، ومن المعروف أن الطفل يولد

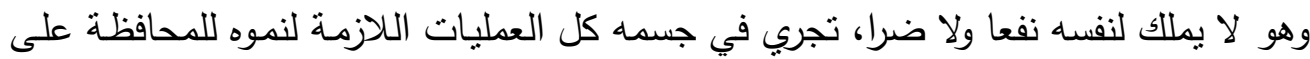
حياته كالتتفس والتمثيل الغذائي، وهو حينما يولد تربطه بالعالم الخارجي حواسه المختلفة التي

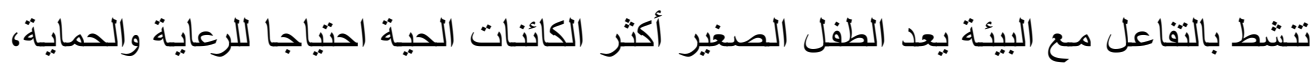
وتعد الملابس أحد وسائل حماية الطفل فهي تحميه من العوامل الخارجية ومن التقلبات الجوية 
المختلفة ولكي تقوم الملابس بهذه الوظيفة يحب أن يراعى عند اختيارها العديد من الشروط

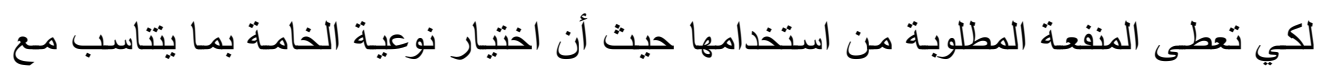

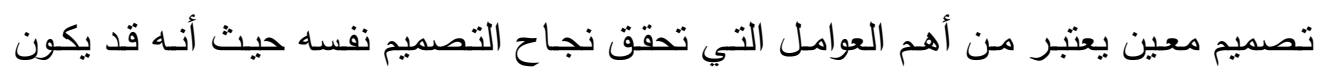

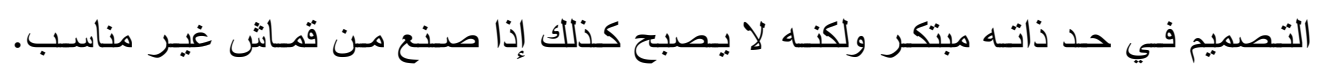

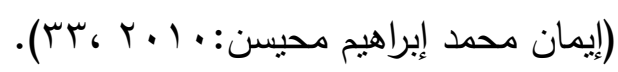

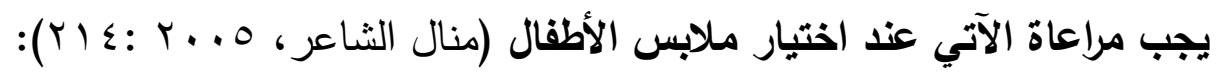

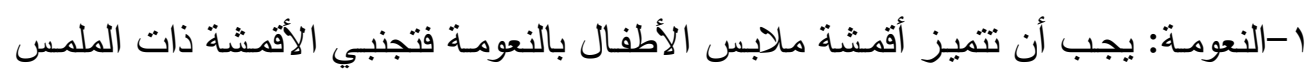
الخشن التي قد تخدش جسم الطفل أو تصيبه بطفح جلدي.

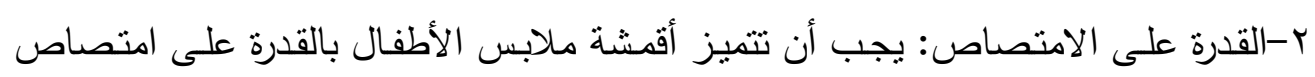

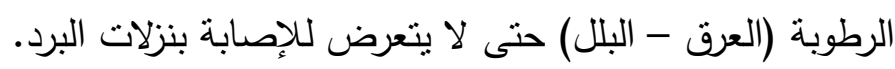

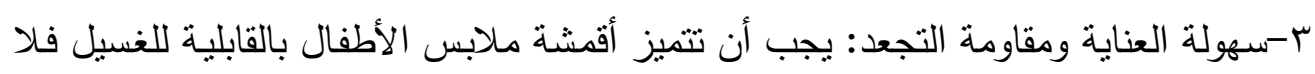
تستخدم الأقشة التي تحتاج إلى نتظيف جافو لا تحتاج للكي. ع - الخلو من الثحنات الكهربائية: حتى لا تسبب أي مضايقات للطفل أثناء احتكاك الملابس

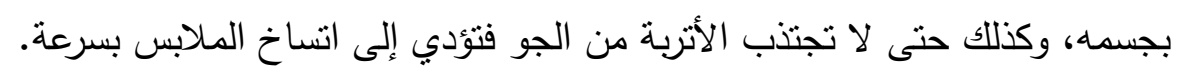

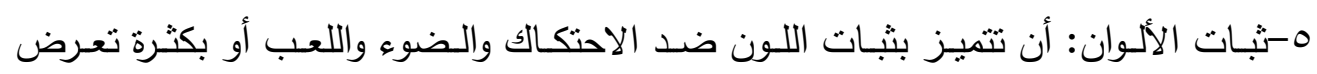
الملابس للأشعة أو يزول لونها مع العرق أو عند وضع الرضيع ملابسه في فمه.

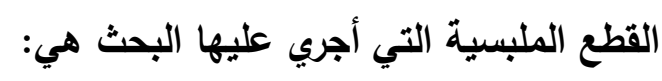

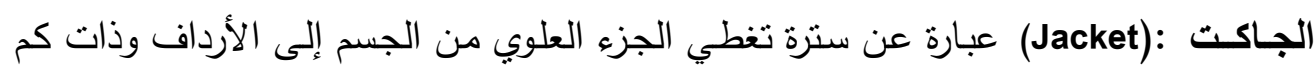

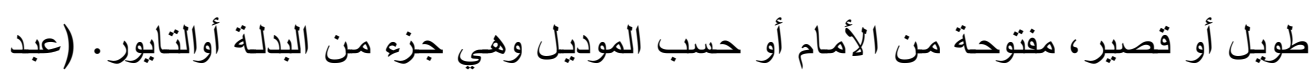

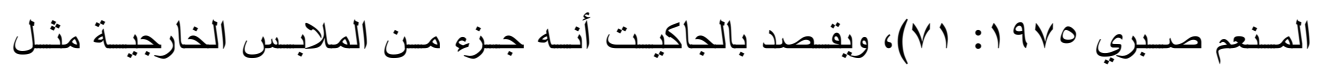
البالطوالقصير يغطي الجزء العلوي من الجسم ويرتديه كل من الجنسين وهو مقتبس من كلمة

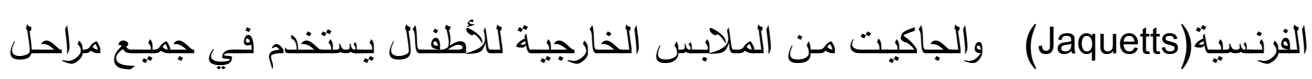
الطفل، وهواما شتوي أو صيفي وفى هذه الحالة يجب ارتدائه على قميص او بلوفر أو فستان،

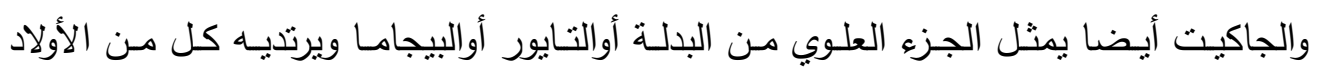

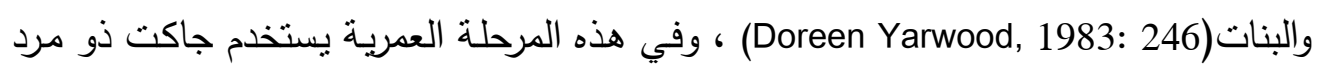
في خط نصف أمامي من أعلى لأسفل وذو خط وسط مطاطي حتى يثبت بمكانه على جسم

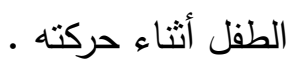


البلوزة أوالقميص (Blouse): عبارة عن رداء يغطي النصف العلوي من الجسم من الكتف

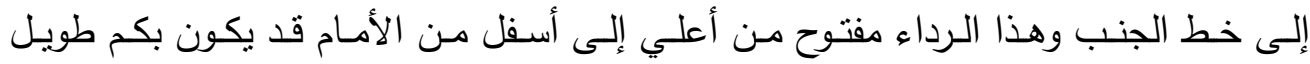

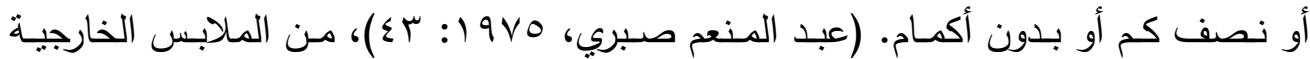

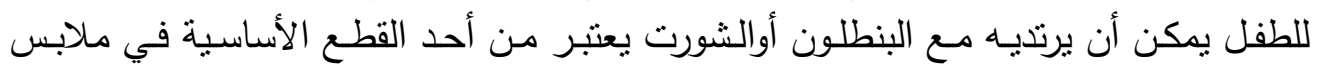

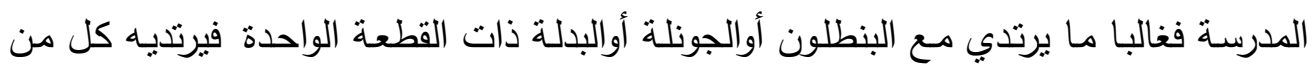

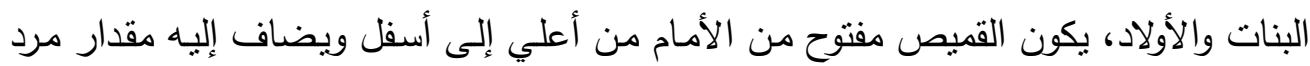

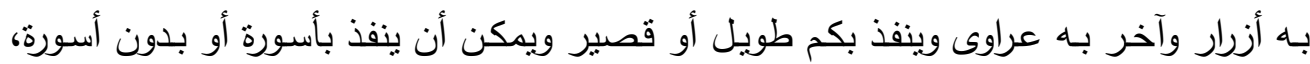
ويمكن أن يحتوي على كول (كول بيبي - كول سبور ، كول شيميزيه).

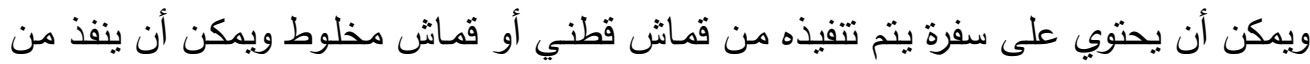

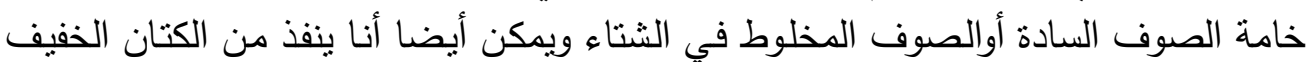

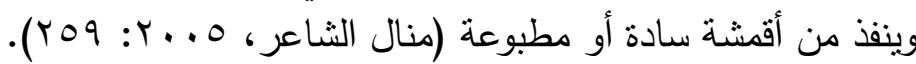

شرائط الساتان Satin Ribbons:

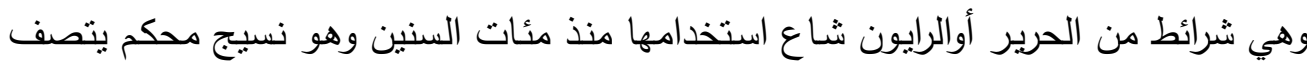

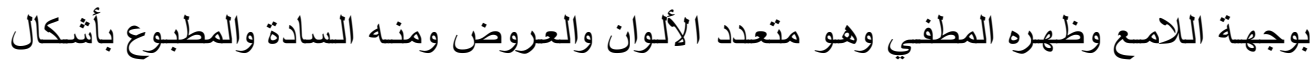
منتوعة (Lawther.G, 1993:6). أحجام وألوان شرائط الساتان المستخدمة في البحث: -

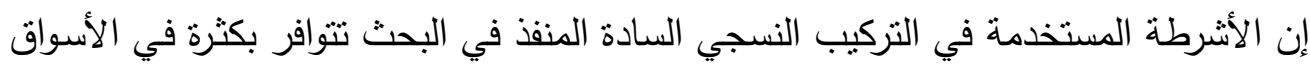

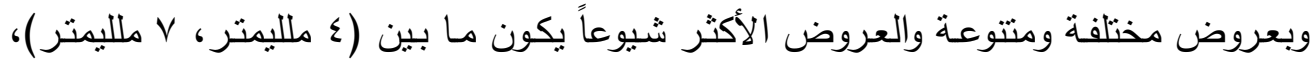
حيث تتعدد ألوان شرائط الساتان. لتنفيذ تجربة البحث الحالي تمث الإجراءات التان التالية:

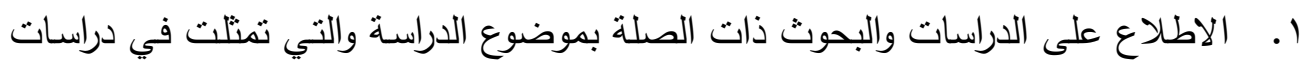

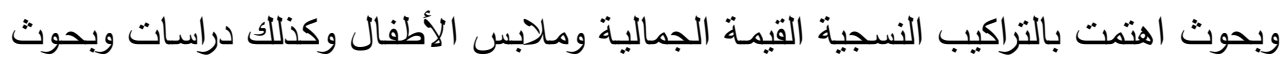

اهتمت بتلاك المجالات.

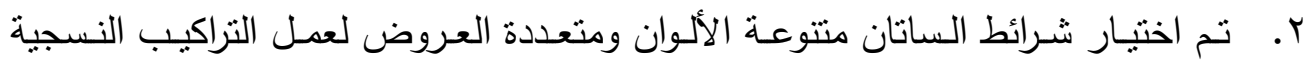

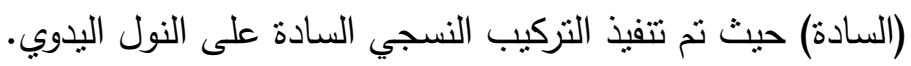

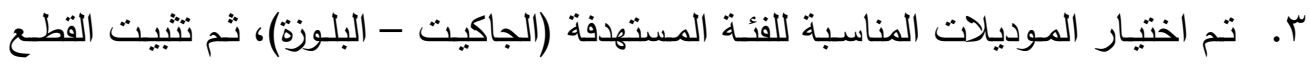
النسجية المنفذة على موديلات ملابس الأطفال وتثبيتها بغرز التطريز المناسبة (السلسلة -

$$
\text { البطانية - البذور ). }
$$

ء. تصميم استمارة تقييم المنتج للموديلات لمعرفة رأي المحكمين بالنسبة للموديلات السبعة من حيث الملاعمة وعدم الملاءمة. ه. تصميم استمارة تقييم المنتج للموديلات لمعرفة رأي المستهلكين بالنسبة للموديلات السبعة

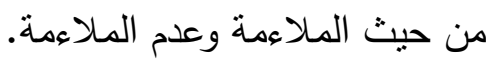
7. عمل تحليل احصائي ورسوم بيانية توضح نتيجة الماعة الانتمارات. 


\section{توصيف موديلات البحث}

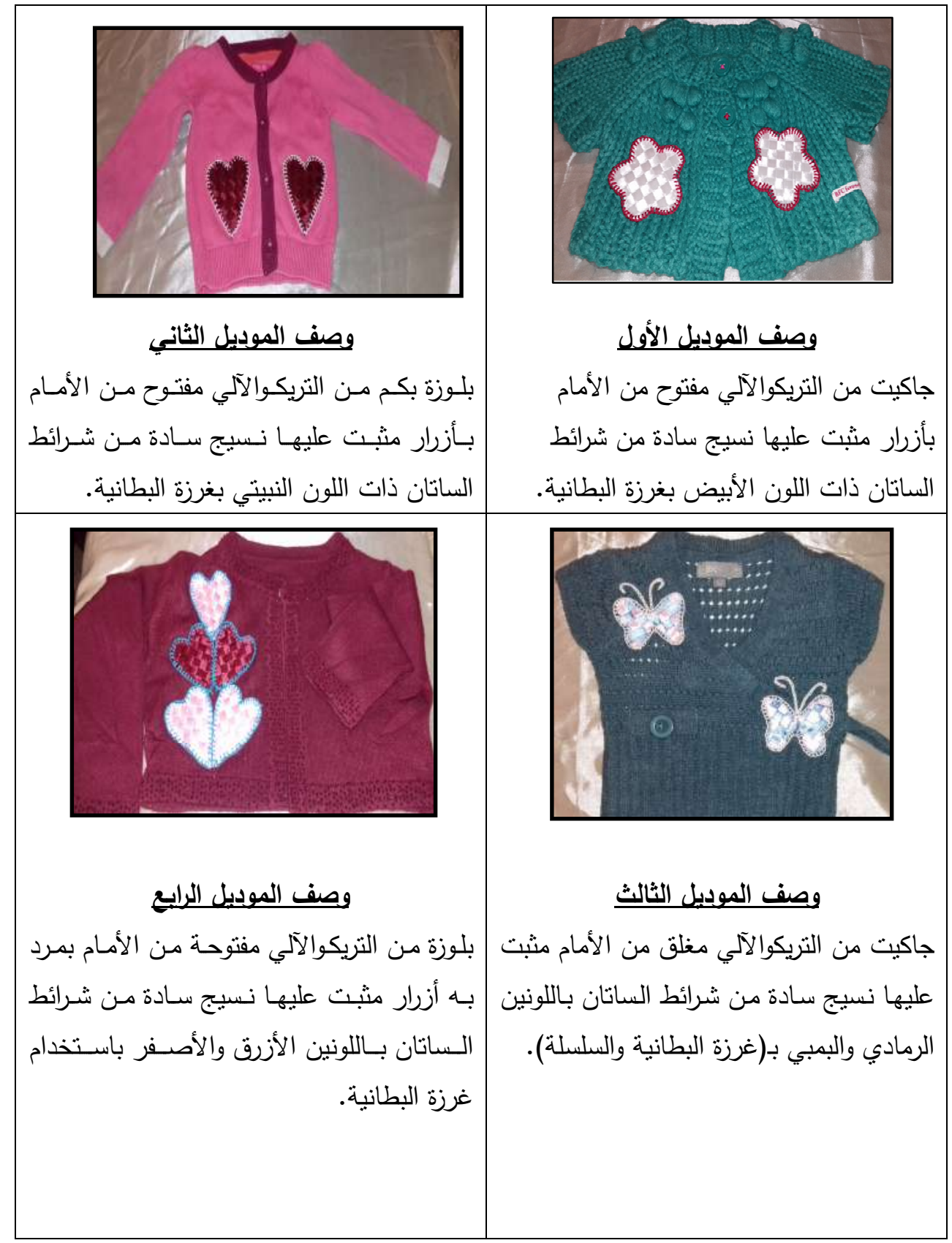




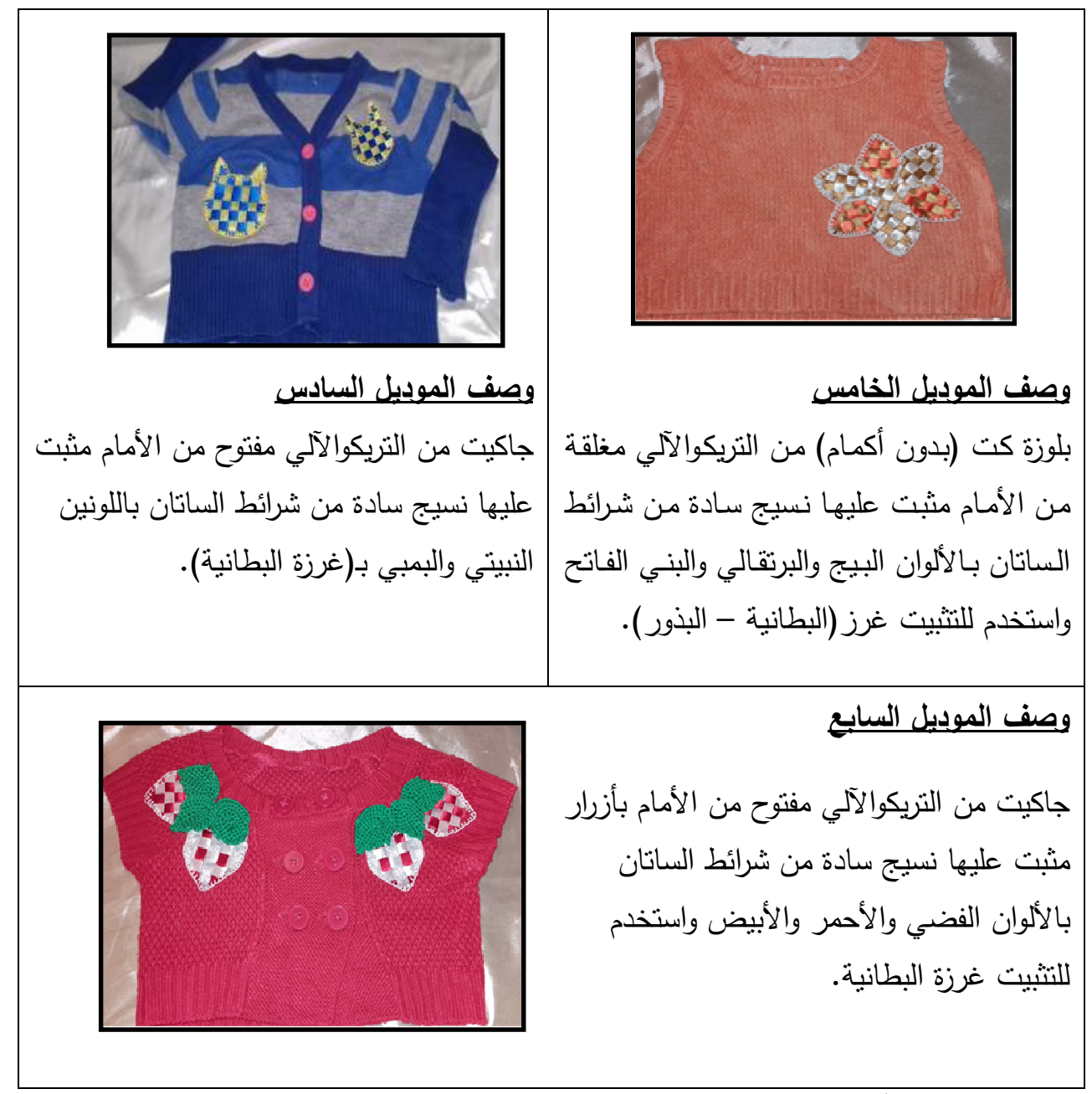

النتائج والمناقشة

أولاً: نتائجج استمارة تقيت المنتجات (المحكم):

تم تقييم الموديلات المنفذة من خلال عمل بطاقة لتقييم الموديلات للمحكمين وبطاقة تقييم للمستهلكين وتم ذلك عن طريق توزبع (بطاقة تقييم المنتج) على عدد (10) من المحكمين للتعرف على آرائهم في هذه الموديلات وعرضهم مرة أخرى على عدد (آ⿱艹 من المستهلكين.

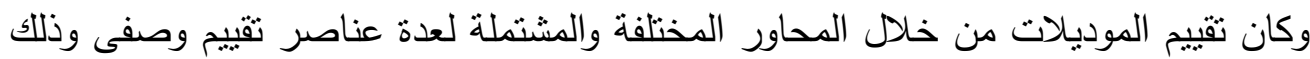
لكل عنصر من عناصر البطاقة من حيث كونه (ملائم - ملائم إلى حد ما - غير ملثم ملائم)

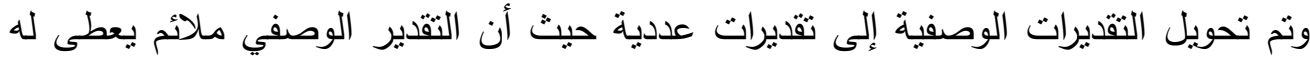

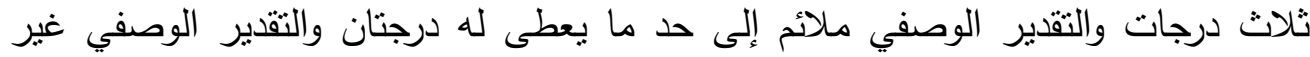
ملأئ يعطى له درجة واحدة، وتم تقييم آراء المحكمين عن طريق حساب المتوسطات الحساب الحسابية

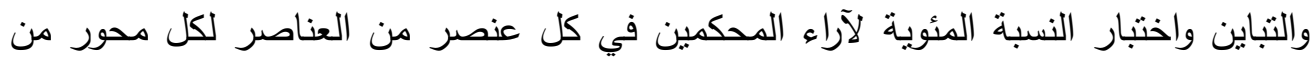
المحاور على حده للموديلات المنفذة، كما تم استخدام تحليل التباين لبيان الاختلاف بين آراء 
المحكمين في المحاور المختلفة، كما تم تحليل البيانات إحصائياً باستخدام تحليل التباين في

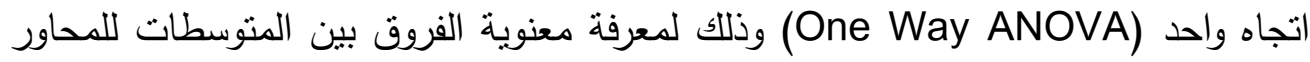
المختلفة لكل موديل، ولكي تتم عملية التقييم الكلى لكل موديل من الموديلات المنفذة.

\begin{tabular}{|c|c|c|c|c|c|c|c|c|}
\hline \multicolumn{7}{|c|}{ اراء المحكين للموديلات من حيث الملاءمة } & \multirow[t]{2}{*}{ المحــــــاور } & \multirow[b]{2}{*}{5} \\
\hline 7 & 7 & 0 & $\varepsilon$ & $r$ & r & 1 & & \\
\hline \multicolumn{9}{|c|}{ المحور الأول : التزاكيب النسيجية } \\
\hline 77 & 54 & 100 & 54 & 92 & 85 & 85 & لتناسب حجم التركيب النسجي المنفذ مع المساحة الكلية & 1 \\
\hline 77 & 62 & 85 & 62 & 92 & 85 & 85 & التصافق التكوين البنائي للتركيب النسجي المنفذ مع خطوط & r \\
\hline 77 & 69 & 100 & 62 & 85 & 85 & 85 & تتاسق ألوان القطعة النسجية المنفذة مع القطعة الملبسية & $r$ \\
\hline 77 & 62 & 100 & 54 & 85 & 85 & 85 & تتاسب التركيب النسجي المنفذ مع المنتج النهائي & $\varepsilon$ \\
\hline 62 & 62 & 100 & 54 & 92 & 85 & 85 & دقه تتفيذ النركيب النسجي المنفذ بشرائط الساتان & 0 \\
\hline 69 & 69 & 100 & 54 & 92 & 77 & 77 & ثبات المظهر السطحي للتركيبات النسجية المنفذة & 7 \\
\hline 46 & 69 & 100 & 54 & 92 & 85 & 85 & تحقق الغرض الجمالي للمنتج النهائي & $\mathrm{V}$ \\
\hline \multicolumn{9}{|c|}{ المحور الثاني: القيم الجمالية } \\
\hline 62 & 69 & 100 & 54 & 100 & 77 & 85 & تحقق النوازن في التصميم & 1 \\
\hline 62 & 54 & 92 & 62 & 100 & 54 & 92 & الإيقاع والحركة في تصميم المنتج & r \\
\hline 62 & 62 & 100 & 8 & 100 & 85 & 77 & الوحدة والترابط بين عناصر التصميح & $r$ \\
\hline 62 & 62 & 100 & 8 & 100 & 69 & 77 & توافق الخامة مع المنتج التصميمي & $\varepsilon$ \\
\hline 62 & 54 & 100 & 8 & 100 & 69 & 85 & النسجي والتتاغم بين التزاكيب النسيجية المستخدمة والتصميم & 0 \\
\hline \multicolumn{9}{|c|}{ المحور الثالث : ملابس الأطفال } \\
\hline 48 & 62 & 100 & 8 & 100 & 69 & 100 & مدى تتاسب ألوان القطعة النسجية المنفذة مع ألوان الموديل & 1 \\
\hline 62 & 85 & 77 & 62 & 100 & 54 & 85 & مدى تتاسب الموديلات مع ملابس الأطفال & r \\
\hline 62 & 69 & 100 & 54 & 100 & 69 & 100 & مدى الاقبال على اختبار ذللك المنتج مع مثيلك في الأسواق & $r$ \\
\hline
\end{tabular}

أولا: تقييم الموديلات السبعة من خلال المحاور المختلفة للبحث من حيث كونهاته (ملائم)

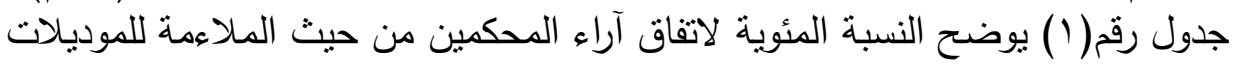

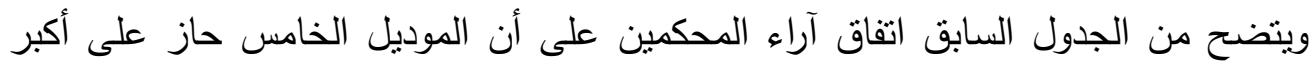

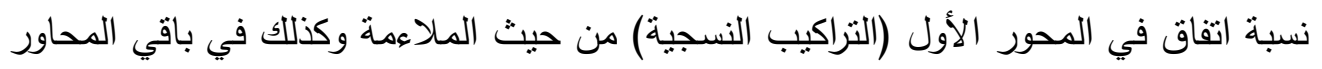

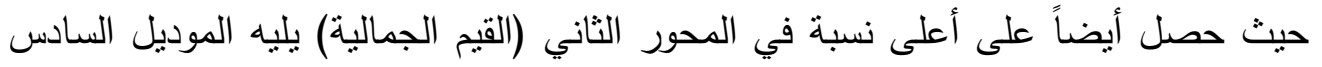

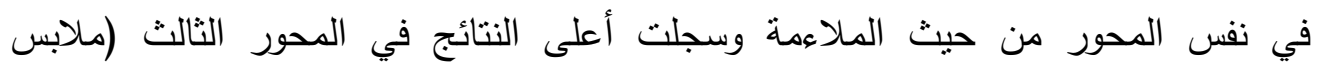

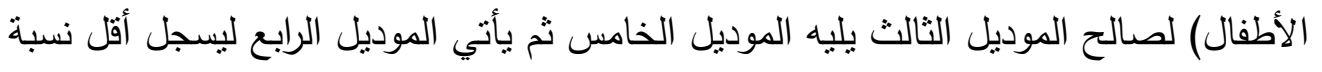

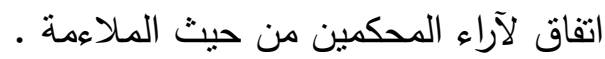




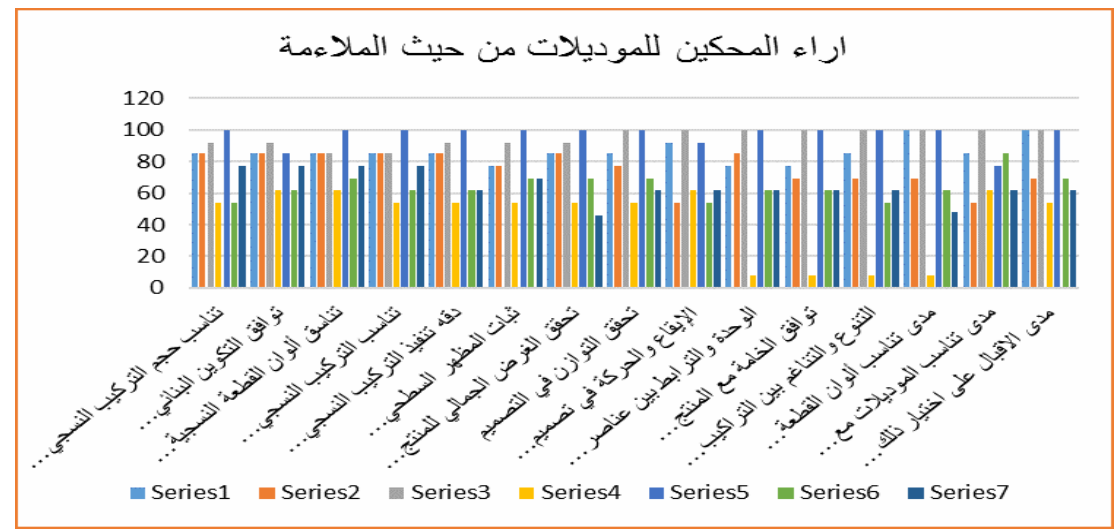

شكل رقم ( ) يوضح نسب اتفاق آراء المحكمين بالنسبة للموديلات السبعة من حيث الملاءمة ثانياً: تقيبم الموديلات السبعة من خلال المحاور المختلفة للبحث من حيث كونه (غير ملائم)

\begin{tabular}{|c|c|c|c|c|c|c|c|c|}
\hline 0 & 15 & 0 & 31 & 0 & 15 & 0 & مدى الاقبال على اختيار ذلك المنتج مع مثيله في الأسواق & $r$ \\
\hline \multicolumn{7}{|c|}{ اراء المحكين للموديلات من حيث عدم الملاءمة } & \multirow[t]{2}{*}{ 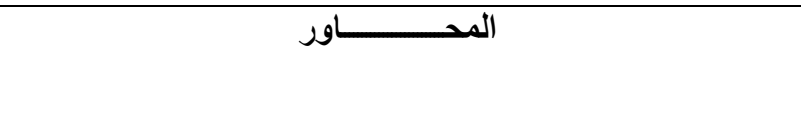 } & \multirow{2}{*}{ p } \\
\hline $\mathrm{V}$ & 4 & 0 & $\xi$ & $r$ & $r$ & 1 & & \\
\hline \multicolumn{9}{|c|}{ المحور الأول : التراكيب النسيجية } \\
\hline 0 & 15 & $\mathbf{0}$ & 31 & 0 & 15 & 0 & تتاسب حجم التركيب النسجي المنفذ مع المساحة الكلية للتصميم & 1 \\
\hline 0 & 15 & 7.5 & 31 & 0 & 15 & 0 & توافق التكوين البنائي للتركيب النسجي المنفذ مع خطوط التصميج & r \\
\hline 0 & 15 & $\mathbf{0}$ & 31 & 8 & 15 & 0 & تتاسق ألوان القطعة النسجية المنفذة مع القطعة الملبسية & $r$ \\
\hline 0 & 15 & 0 & 31 & 8 & 15 & 0 & تتاسب التركيب النسجي المنفذ مع المنتج النهائي & $\varepsilon$ \\
\hline 0 & 15 & 0 & 31 & 0 & 15 & 0 & دقه تتفيذ التركيب النسجي المنفذ بشرائط الساتان & 0 \\
\hline 0 & 15 & $\mathbf{0}$ & 31 & $\mathbf{0}$ & 15 & $\mathbf{0}$ & ثبات المظهر السطحي للتركيبات النسجية المنفذة & 7 \\
\hline 0 & 15 & $\mathbf{0}$ & 31 & $\mathbf{0}$ & 15 & $\mathbf{0}$ & تحقق الغرض الجمالي للمنتج النهائي & $\begin{array}{c} \\
\end{array}$ \\
\hline \multicolumn{9}{|c|}{ المحور الثاني: القيم الجمالية } \\
\hline $\mathbf{0}$ & 15 & $\mathbf{0}$ & 31 & 0 & 15 & 0 & تحقق التوازن في التصميم & 1 \\
\hline 0 & 15 & 5 & 38 & $\mathbf{0}$ & 15 & $\mathbf{0}$ & الإيقاع والحركة في تصميم المنتج & $r$ \\
\hline 0 & 15 & 0 & 38 & 0 & 15 & 0 & الوحدة والترابط بين عناصر التصميم & $r$ \\
\hline 0 & 15 & 0 & 38 & 0 & 15 & 0 & نوافق الخامة مع المنتج التصميمي & $\xi$ \\
\hline 0 & 15 & 0 & 31 & 0 & 15 & 0 & التتوع والتتاغم بين التراكيب النسيجية المستخدمة والتصميم النسجي & 0 \\
\hline \multicolumn{9}{|c|}{ المحور الثالث : ملابس الأطفال } \\
\hline 0 & 15 & $\mathbf{0}$ & 31 & 0 & 15 & 0 & مدى تتاسب ألوان القطعة النسجية المنفذة مع ألوان الموديل & 1 \\
\hline $\mathbf{0}$ & 15 & $\mathbf{0}$ & 38 & 5 & 7.5 & $\mathbf{0}$ & مدى تتاسب الموديلات مع ملابس الأطفال & r \\
\hline
\end{tabular}


ويتضح من الجدول السابق اتفاق آراء المحكين على أن الموديل الرابع حاز على أكبر نسبة اتفاق في المحور الأول (النراكيب النسجية) من حيث عدم الملاعمة وكذلك في باقي المحاور حيث حصل أيضاً على أعلى نسبة في المحور الثاني (القيم الجمالية) يليه الموديلين الثاني والسادس في نفس المحور من حيث عدم الملاءمة وسجلت أعلى النتائج في المحور الثالث (ملابس الأطفال) لصالح الموديل الرابع يليه الموديل الثاني والسادس ثم يأني الموديلين الأول والسابع ليسجل أقل نسبة اتفاق لآراء المحكمين من حيث عدم الملاعهة.

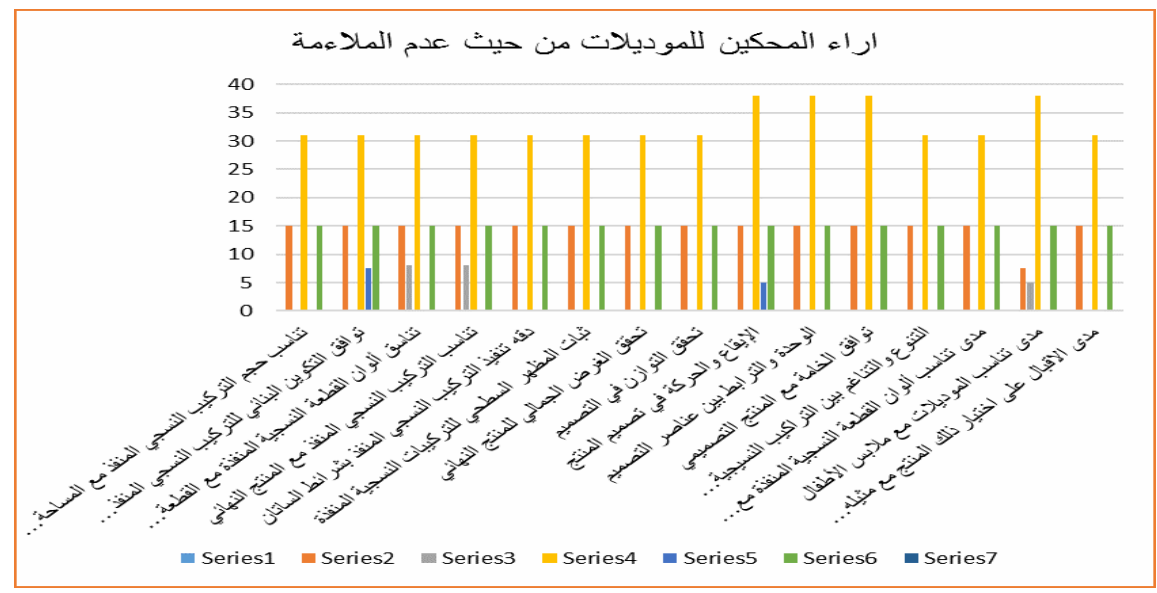

شكل رقم (Y) يوضـح نسب اتقاق آراء المحكمين بالنسبة للموديلات من حيث عدم الملاعمة

ومن خلال آراء المحكمين ونسبة الاتفاق على الموديلات المنفذة نجد أنها نسبة مرضية

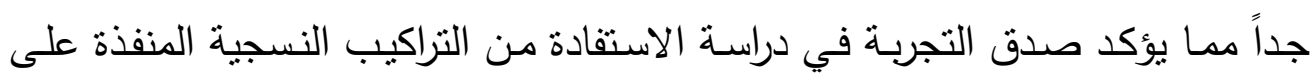

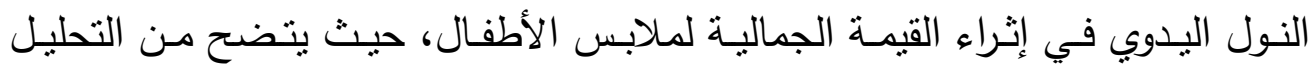

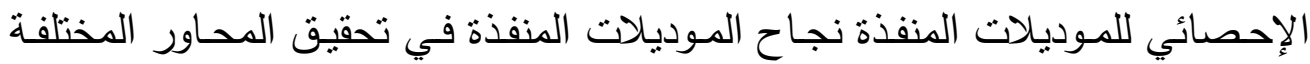
فنجد تميز الموديلات المنفذة في وملاعمنها للفئة المستهدفة. ثانياً: نتائج استمارة تقييم المنتجات (المستهبلك): تم تقييم الموديلات المنفذة من خلال عمل بطاقة لتقييم الموديلات للمستهلكين وتم ذلك

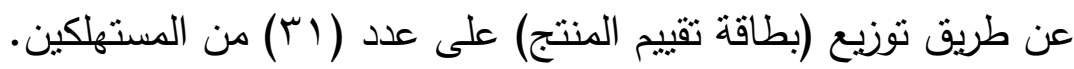

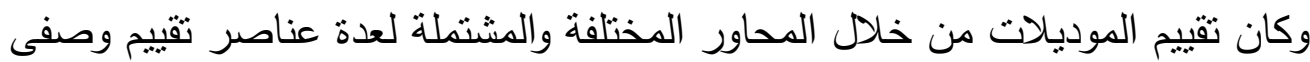

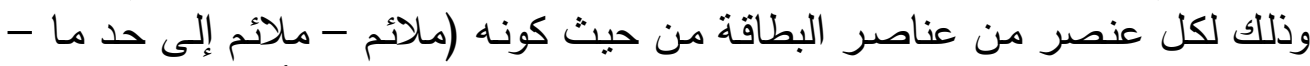
غير ملائم) وتم تحويل التقديرات الوصفية إلى تقديرات عددية حيث أن التقدير الوصفي ماند 


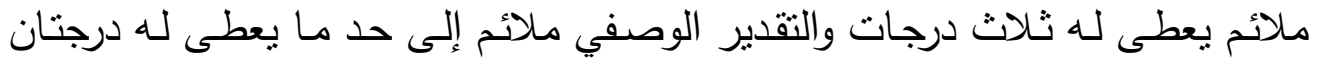

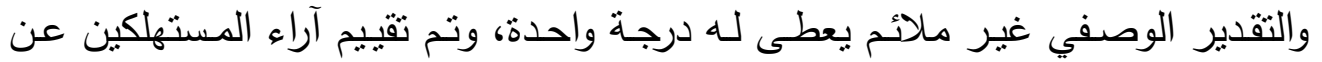

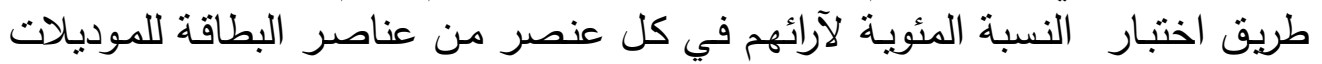

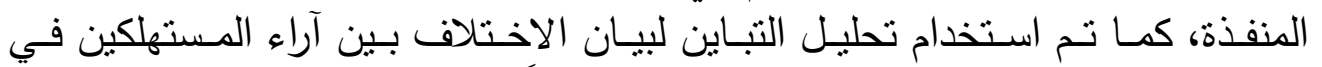
العناصر المختلفة، كما تم تحليل البيانات إحصائياً باستخدام تحليل التباين في اتجاه التهاه

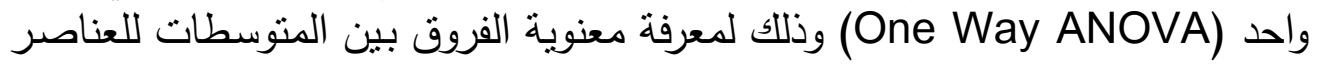

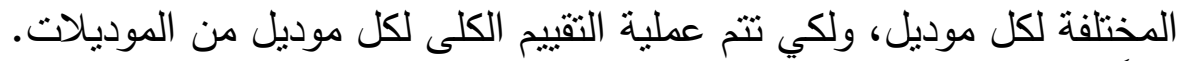

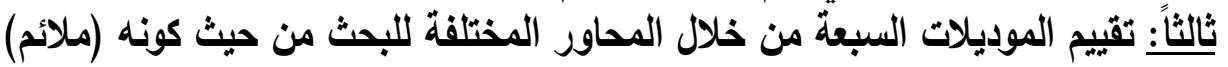

\begin{tabular}{|c|c|c|c|c|c|c|c|c|}
\hline \multicolumn{7}{|c|}{ اراء المستهلكين للموديلات من حيث الملاءمة } & \multirow[t]{2}{*}{ عناصر البطاقة } & \multirow{2}{*}{ p } \\
\hline V & 1 & 0 & $\varepsilon$ & $r$ & r & 1 & & \\
\hline 100.0 & 96.7 & 100.0 & 96.7 & 56.7 & 66.7 & 80.0 & مستوى الابتكار والتجديد في الموديل & 1 \\
\hline 76.7 & 80.0 & 76.7 & 80.0 & 60.0 & 76.7 & 73.3 & بالشرائط للموديل التركيب النسجي المنفذ & r \\
\hline 90.0 & 86.7 & 90.0 & 96.7 & 70.0 & 70.0 & 90.0 & مدى احتواء الموديل للتميز والأصالة & $r$ \\
\hline 80.0 & 86.7 & 80.0 & 90.0 & 63.3 & 56.7 & 80.0 & مناسبة الموديل للذوق العام & $\varepsilon$ \\
\hline 90.0 & 86.7 & 90.0 & 96.7 & 73.3 & 60.0 & 73.3 & مدى مسايرة الموديل للموضة & 0 \\
\hline 93.3 & 96.7 & 93.3 & 100.0 & 70.0 & 86.7 & 86.7 & مدى تلتاسب ألوان الموان القطعة النسجية & 7 \\
\hline 83.3 & 100.0 & 83.3 & 100.0 & 86.7 & 73.3 & 93.3 & المدنى تتاسب خامة في القطعة الشرائط & v \\
\hline 93.3 & 93.3 & 93.3 & 76.7 & 80.0 & 73.3 & 76.7 & للفئة المستة ألوان القطعة النسيجية المنفذة & $\wedge$ \\
\hline 93.3 & 83.3 & 100.0 & 93.3 & 86.7 & 86.7 & 76.7 & للفئة المستة المظهرة العام للقطعة المنفذة & 9 \\
\hline
\end{tabular}

جدول رقم (r) يوضح النسبة المئوية لاتفاق آراء المستهلكين من حيث الملاءمة

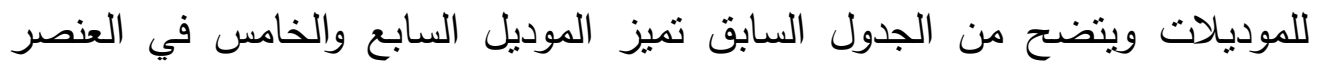

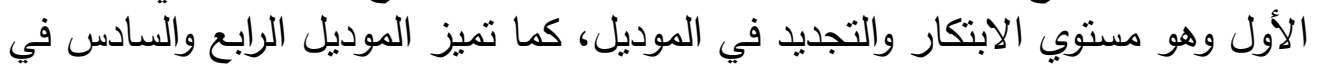

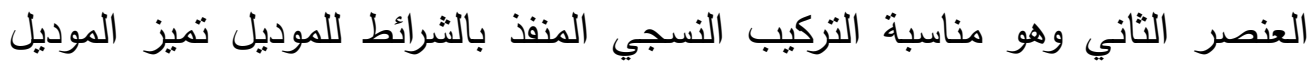

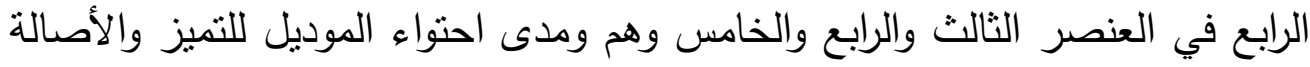

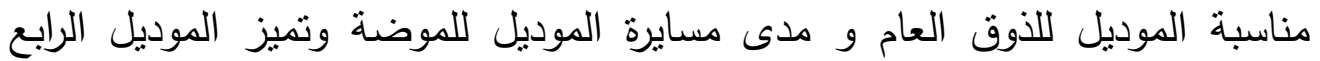

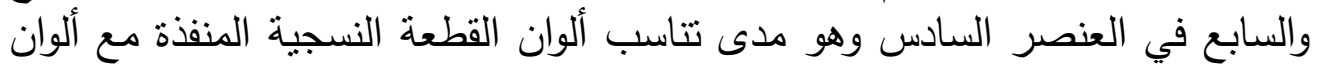

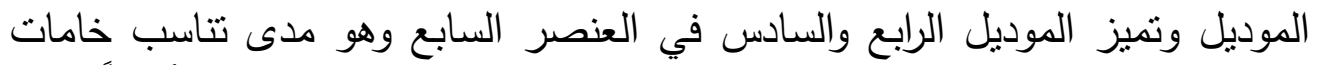
الثرائط المستخدمة في القطعة النسجية المنفذة مع خامات الموديل ولمديل وأيضاً تميز خدات 
الموديل السادس في العنصر الثامن وهو مناسبة ألوان القطعة النسيجية المنفذة للفئة

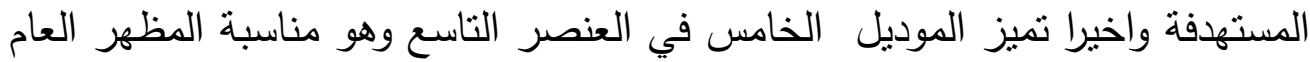

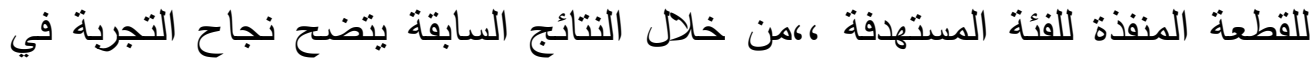
دراسة الاستفادة من التراكيب النسجية المنفذة على النول اليدوي في إثراء القيمة الجمالبة لملابس الأطفال.

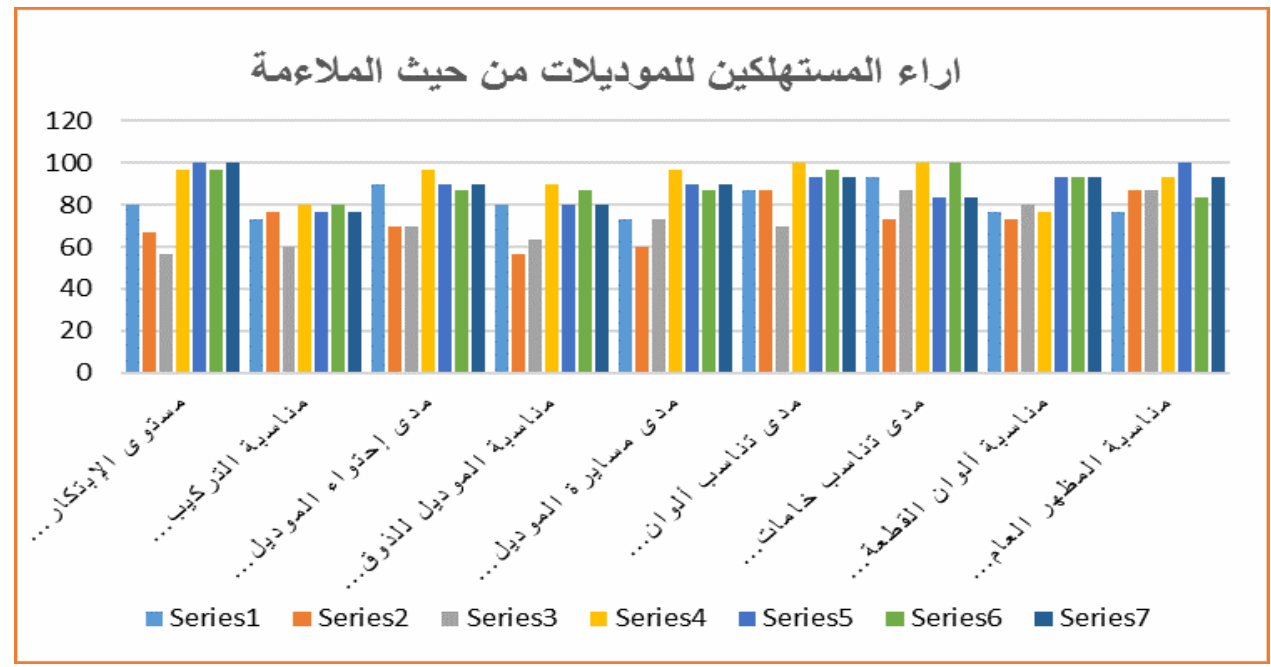

شكل رقم (r) يوضح نسب اتفاق آراء المستهلكين بالنسبة للموديلات من حيث الملاءمة

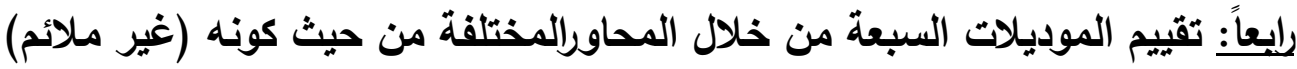

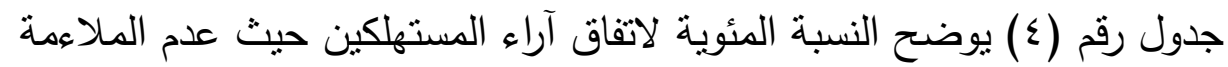
للموديلات

\begin{tabular}{|c|c|c|c|c|c|c|c|c|}
\hline \multicolumn{7}{|c|}{ اراء المستهلكين للموديلات من حيث عدم الملاءمة } & \multirow[t]{2}{*}{ عناصر البطاقة } & \\
\hline $\bar{v}$ & 7 & 0 & $\varepsilon$ & $r$ & r & $T$ & & \\
\hline 0.0 & 0.0 & 0.0 & 0.0 & 6.7 & 10.0 & 0.0 & مستوى الابتكار والتجديد في الموديل & 1 \\
\hline 3.3 & 0.0 & 3.3 & 0.0 & 10.0 & 6.7 & 3.3 & بالشرائط للموديل التركيب النسجي المنفذ & r \\
\hline 0.0 & 0.0 & 0.0 & 0.0 & 16.7 & 10.0 & 0.0 & مدى احتواء الموديل للتميز والأصالة & $r$ \\
\hline 0.0 & 0.0 & 0.0 & 0.0 & 0.0 & 13.3 & 3.3 & مناسبة الموديل للذوق العام & $\varepsilon$ \\
\hline 0.0 & 0.0 & 0.0 & 0.0 & 10.0 & 13.3 & 0.0 & مدى مسايرة الموديل للموضة & $\circ$ \\
\hline 0.0 & 0.0 & 0.0 & 0.0 & 16.7 & 0.0 & 3.3 & المنفذة تناسب ألوان الموان القطعة النسجية & 7 \\
\hline 0.0 & 0.0 & 0.0 & 0.0 & 6.7 & 3.3 & 0.0 & 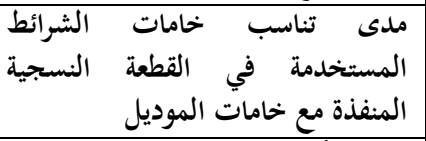 & v \\
\hline 0.0 & 0.0 & 0.0 & 0.0 & 3.3 & 13.3 & 0.0 & منلفئة المستة ألوان القطعة النسيجية المنفذة & $\wedge$ \\
\hline 0.0 & 0.0 & 0.0 & 3.3 & 6.7 & 3.3 & 0.0 & ملفئة المستهلة المظهر العام للقطعة المنفذة & 9 \\
\hline
\end{tabular}


بتضح من الجدول السابق العناصر المختلفة لجميع الموديلات وترتيبها تبعاً لتحقيقها

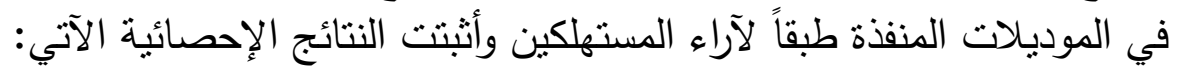

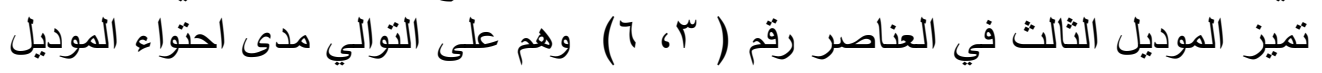

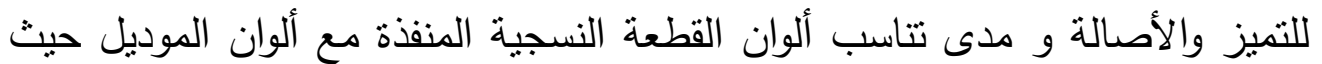

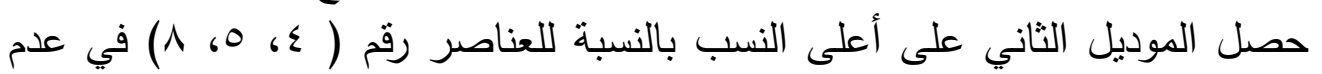

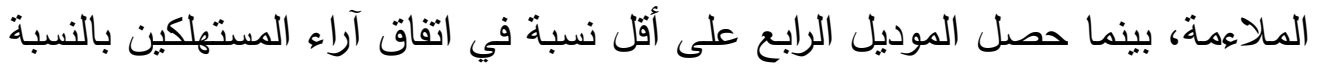

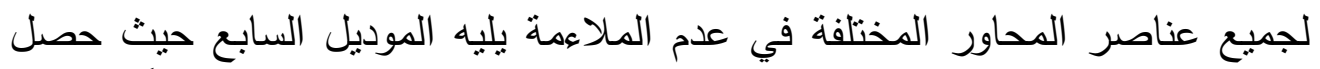

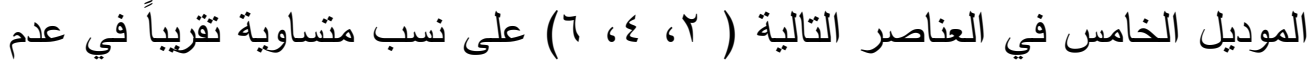
الملاعمة من خلا النتائج السابقة يتضح فناهي ناح التجربة في الاستفادة من التراكيب النسجية المنفذة على النول اليدوي في إثراء القيمة الجمالية لملابس الأطفال.

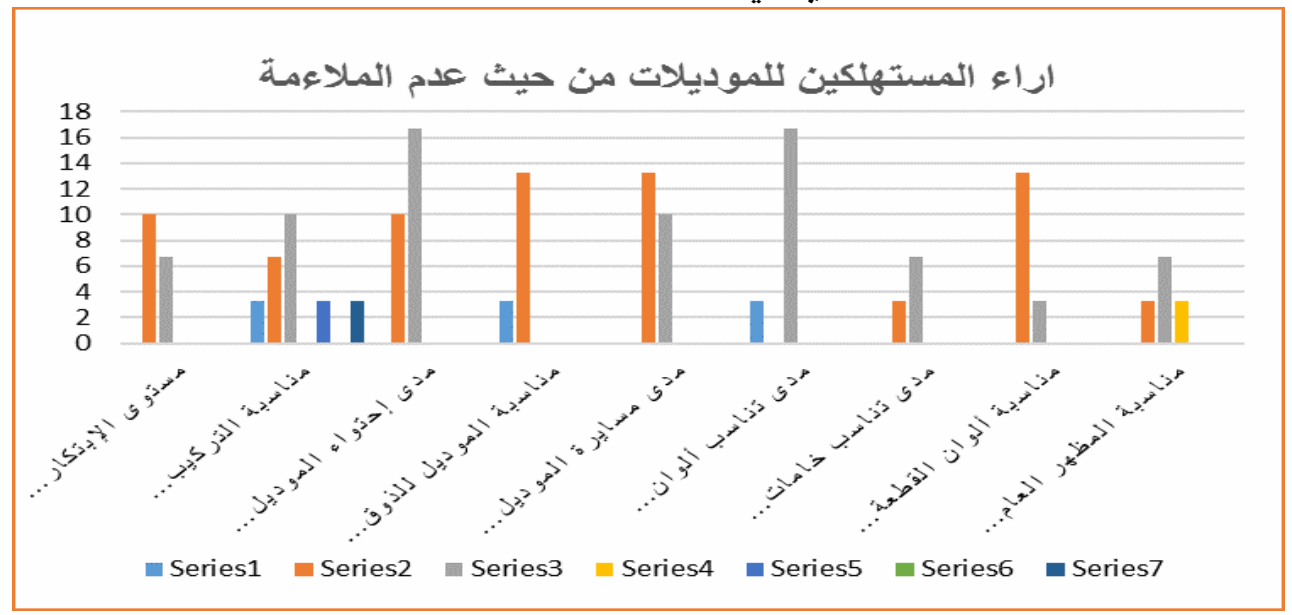

شكل رقم (£) يوضح نسب اتفاق آراء المستهلكين من حيث عدم الملاءمة للموديلات

ملخص النتائج أثبتت النتائج والتحليلات الإحصائية صحة الفروض التالية: ا.توجد علاقة ذات دلالة إحصائية بين درجة قبول ونجاح الملابس المنفذة ومدى الألئ

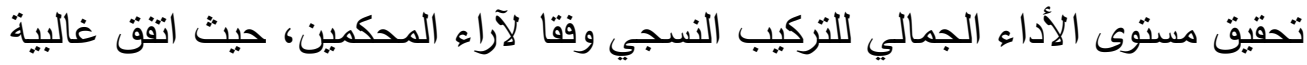
المحكمين على أن الموديل الخامس والثالث أكثر الموديلات تحقيقاً لهذا الفرض الألئ يليه

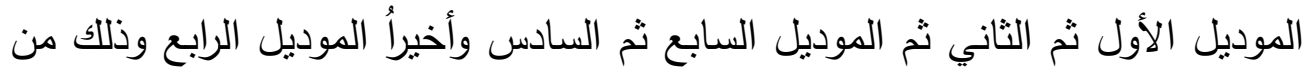
حيث الملاعمة. r.توجد علاقة ذات دلالة إحصائية بين درجة قبول ونجاح الملابس المنفذة ومدى الأى

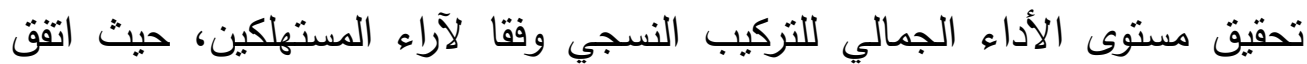
غالبية المستهكين على أن الموديل الخامس والموديل الرابع أكثر الموديلات تحقيقاً 
لهذا الفرض يليه الموديل السابع ثم الموديل السادس ثم الموديل التاسع ثم الموديل

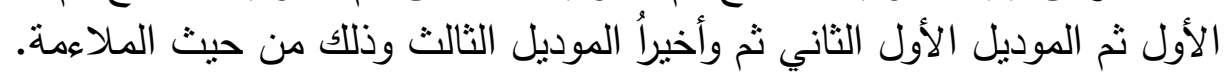
ومن خلال ما سبق تتلخص نتائج الاراسة في التول التقاط التالية:

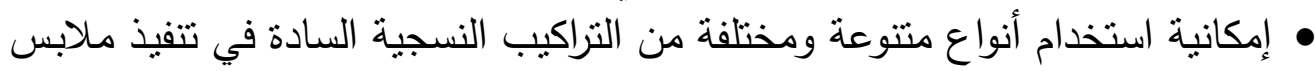
الأطفال وذللك لإثراء القيم الجمالية. سـهولة استخدام الأنسجة السادة في تتفيذ أشكال تثري ملابس الأطفال جمالاً لقلة

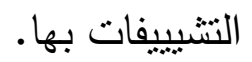
• إمكانية تتفيذ التراكيب النسيجية بشرائط الساتان على العديد من مكملات الملابس.

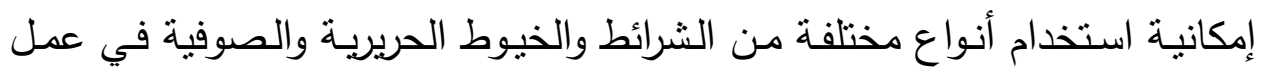
نسجيات تثري الملابس والمفروشات جمالا ورونقا. توصبيات البحث: 1 - الاهتمام بكل ما هو جديد في مجال ملابس الأطفال. r- الاستفادة من التراكيب النسجية المنتجة على هلى النول اليدوي لإثراء القيم الجمالية للمفروشات المنزلية. r- الاستفادة من الخيوط المعدنية منل السيرما في الحصول على تراكيب نسجيه لإثراء

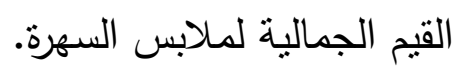
ع - الاهتمام بطرق العناية بالتراكيب النسجية المنفذة على النول اليدوي وعمل بطاقات ارشادية للعناية بها. 
" تأثير اختلاف بعض التراكيب البنائية والتصميم على خواص "اصل

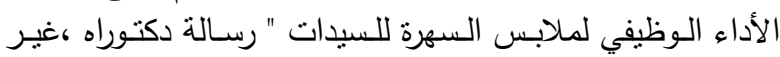

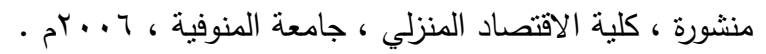

الكـزج بـين التراكيب النسجية سـابقة التجهيز والطـرق الطباعيـة

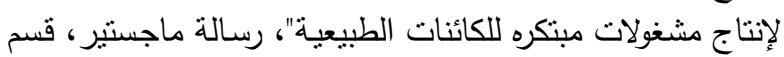

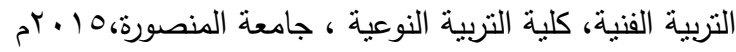

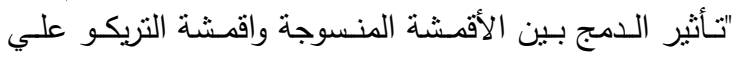

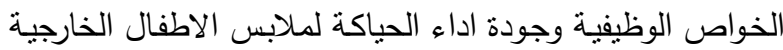

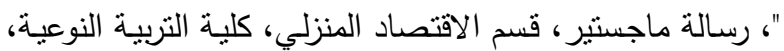

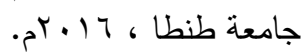
" دراسـات في النسيج “" دار الفكر العربـي ، الطبعـة الخامسسة ،

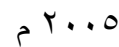

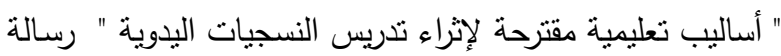

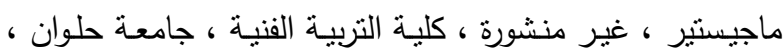
. م. ماجن "إمكانيـة نوظيف اللاسيه فنيـا وجماليـا في عمل ملابس السهرة

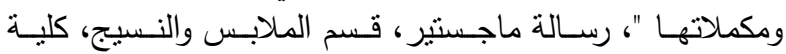

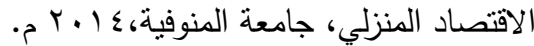
تأثنير اختلاف بعض الأساليب التطبيقية للمنتج الملبسي للأطفال

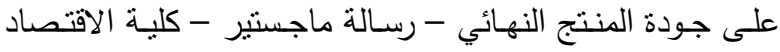

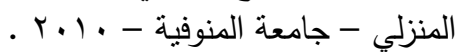

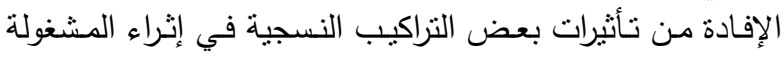

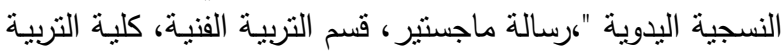

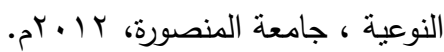

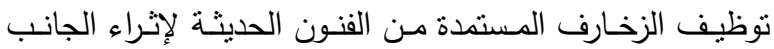

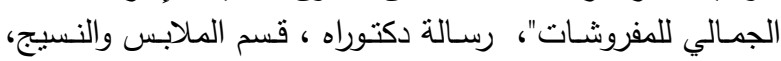

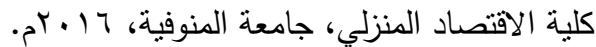

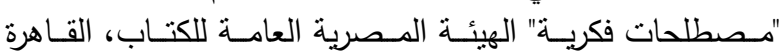
.0) $99 \mathrm{~V}$ 。 " موسـوعة الملابسـ " عـالم الكتب، القـاهرة ، الطبعـة الأولـي ، - م) $99 \mathrm{~V}$ " الاستفادة من الفروالصناعي في اثراء القيمة الجمالية والوظيفية

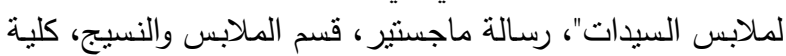

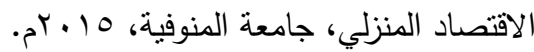

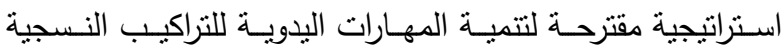

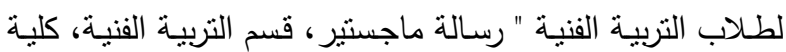

المراحع المستخدمة في البحث: ا ـ أسمهان إسماعيل النجار: r. ا شرف عبدالرحمن قتديل: r. السيدة فتح الله حسب الله: ؛ ـ أنصاف نصر وكوثر الزغبي: هـ أمل فاروق عبد العظيم عوض: צ. . إيمان حسين عبد العال: V. إيمان محمد إبراهيم محيسن: ^. بسمه على السيد زلط: 9 ـ . حنان محمود سمحان: . 1 . 11 .سامية إبراهيم السمان : r ا.شيماء حمدي مصطقي: با ـداليا إبراهيم عفيفي: 


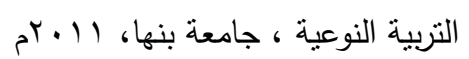

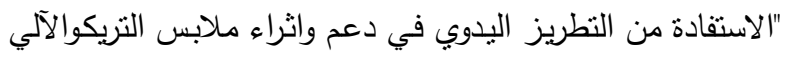

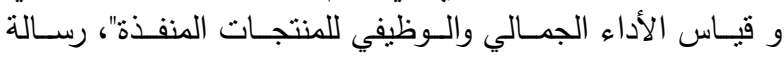

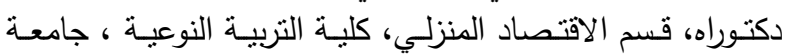

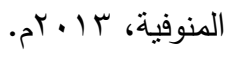

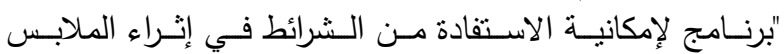

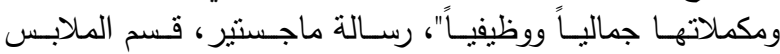

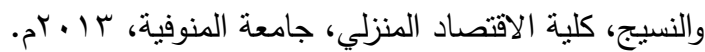

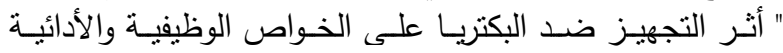

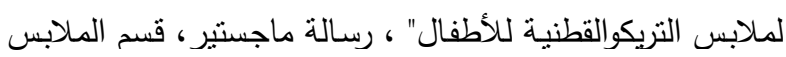

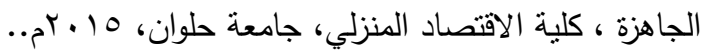

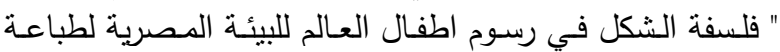

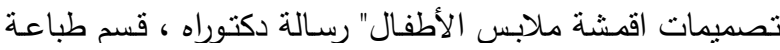

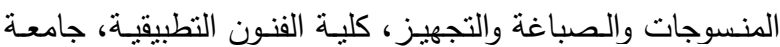

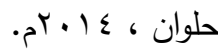

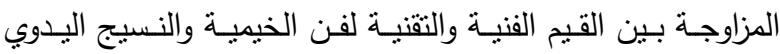
لاستحداث مشغولات نسجيه معاصرة"، رسالة دكتوراه، قسم التربية

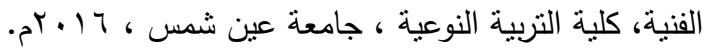

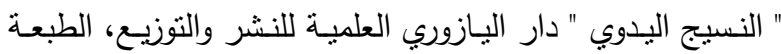

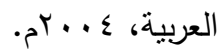
سيكولوجية ملابس الأطفال وطرق تتفيذها - القاهرة - دار الفكر

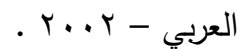
" دراسـات في النسيج وأسس تتفيذ الملابس " دار الفكر العربي،

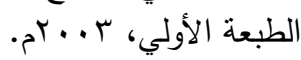

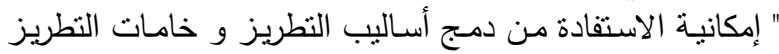

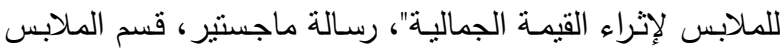

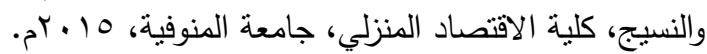

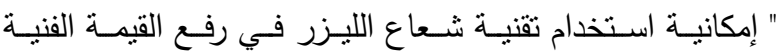

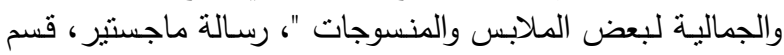

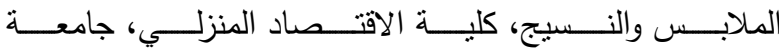

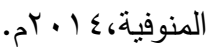
دراسـة تحليليـة للزخـارف في كمن عصر ملـوك الطوائف والإفـادة منها في ابتكار

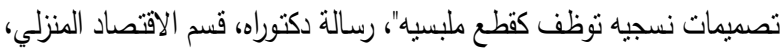

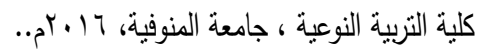

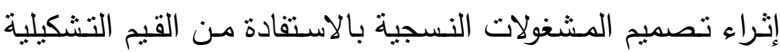

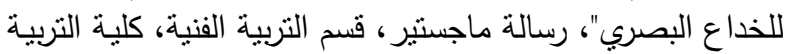

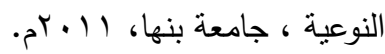

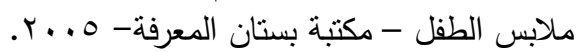

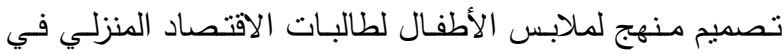

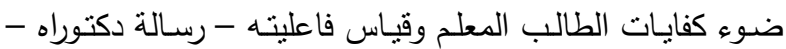

؛ إعاء محمد الدالي:

1 1 رحاب ماهر مصطفى :

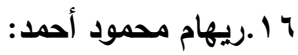

Vهاء محمود عبد التبي امام: V V

1 ا.عتاب نبيل سيد أحمد:

9 1 . عصـام ظاظا وآخرون : : . . علية عابدين .

ا Y.علية عابدين وزينب الدباغ : r Y Y . هبة حسن إبراهيم: r. هبه رزق الله شاكر : צ r . هبة عبدالله بسيوني: هץ.مروى أحمد عبد الرحمن: Y Y.منا موسـي، نجدة ماضي:

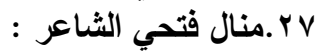


كلية التربية النوعية - جامعة عين شمس -ه . . ؟.

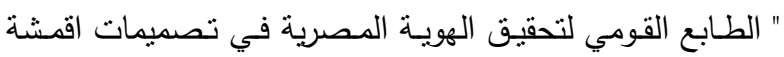
^ץ بـه الله اسامة سعد:

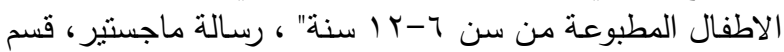

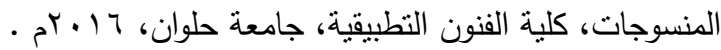

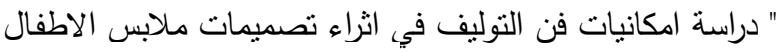

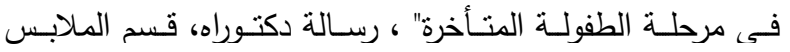

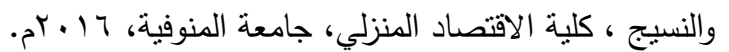

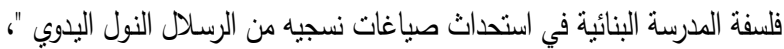

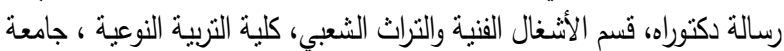

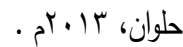
القيم الجمالية للنسيج المزدوج والاستفادة منها في اثراء المشغولة التهاء

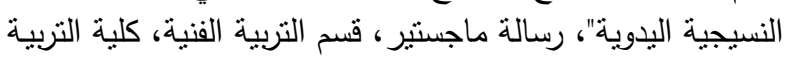

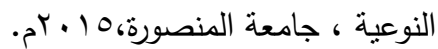

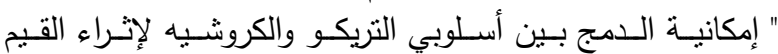

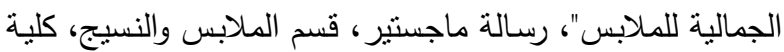

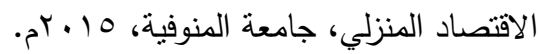

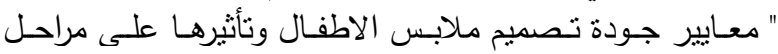

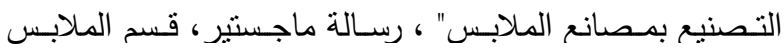

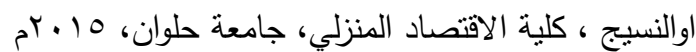

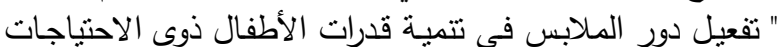

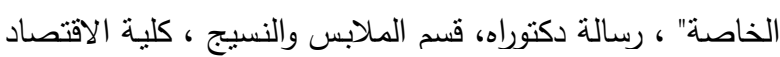

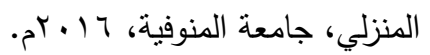

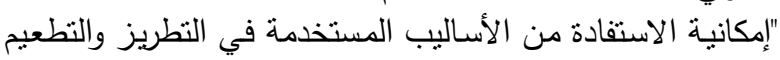

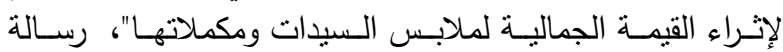
دكتوراه، قسم الاقتصاد المنزلي، كلية التربية النوعية، جامعة بنهاء المها، (T)

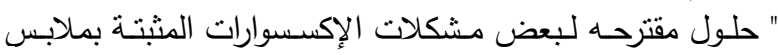

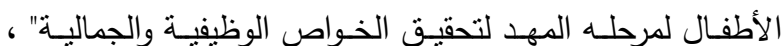

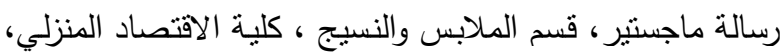
9 ب.منى سمير فتوح جميل:

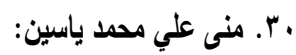
اس.مها صلاح كامل غراب: r r.نجوان فؤاد السيد محمد:

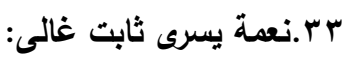
ع آنهى عبد الحليم عبد الله : هr.نيفين عبد الوكيل عطا : צr. وليد نبيه عبد العاطي قاسم:

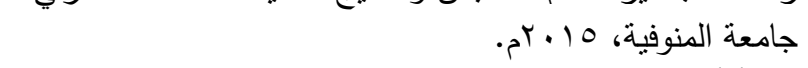

37. John gillow and Bryan sentence: "World Textile", Thames \& Hu dson 1td, London, 1999.

38. Scrivano, Sandy: Sewing with leather and suede, Asheville, north, cardinal, 1998.

39. Www.Wikipidia.com 3/1/2017 